\title{
47. Klasik Türk şiirinde yağmurla ilgili tasavvurlar
}

\section{Semih YEȘILBAĞ $\breve{1}^{1}$}

APA: Yeşilbă̆, S. (2021). Klasik Türk şiirinde yağmurla ilgili tasavvurlar. RumeliDE Dil ve Edebiyat Araşttrmaları Dergisi, (24), 807-853. DOI: 10.29000/rumelide.995450.

\section{$\ddot{\mathbf{O z}}$}

Klasik Türk edebiyatı sahasındaki eserler incelendiğinde bu edebiyatta sevgi ve aşk dışında, kozmografik unsurlardan bitkilere; dinî ilimlerden batıl inanışlara; ayet, hadis iktibaslarından deyimlere kadar sosyal hayat içerisindeki iğneden ipliğe her şeye farklı bağlam ve vesilelerle yer verildiği görülmektedir. Bu bağlamda yağmur da şairlerin duygu, düşünce ve hayal dünyası içerisinde yer alan ve nispeten yaygın kullanımı olan bir temadır. Bu çalışmada isimleri kaynakçada yer alan 16. yüzyılda yaşamış 25 klasik Türk şairinin doğrudan yağmuru ele alan ya da bulut, dağ, gök gürültüsü gibi dolaylı olarak yağmurla irtibatlandırılan unsurları ihtiva eden beyitleri, ilgili divanlar taranarak tespit edilmiştir. Ardından tespit edilen beyitler, yağmurla ilişkilendirilen tabî unsurlar; yağmurla benzetme veya mecaz ilgisi yoluyla ilişkilendirilen unsurlar; yağmurla ilgili âdet, inanış ya da tecrübeye dayah bilgiler; yağmurla ilgili ayet, hadis ve deyimler; yağmurla ilgili diğer unsurlar alt başlıklarıyla incelemeye tabi tutulmuştur. Verilen bilgileri desteklemek için çalışmaya dâhil edilmiş örnek beyitler, makalenin bağlamına uygun olarak tasnif edilmiş ve açıklanmıştır. Yağmur ana başlığı çerçevesinde oluşturulan alt başlıklarla hazırlanan bu çalışmada klasik Türk edebiyatı şairlerinin yağmuru nasıl algıladıkları, hangi anlamlarla ve hangi unsurlarla irtibatlandırdıkları, yıllar içinde toplumsal ve kültürel hayat bağlamında yağmurla ilgili nasıl bir duygu, düşünce ve hayal dünyasının oluştuğu ortaya konulmaya çalışılmıştır.

Anahtar kelimeler: Klasik Türk edebiyatı, yağmur, bârân, matar

\section{Concepts of rain in classical Turkish poetry}

\begin{abstract}
When the works in the field of classical Turkish literature are examined, it can be seen that apart from love, everything in social life from A to $\mathrm{Z}$, from cosmographic elements to plants, from religious sciences to superstitions, from hadith quotations to idioms, is included in this literature with different contexts and means. In this context, rain is also a theme which appears in the emotions, thoughts and imaginations of poets and which has a relatively common use. In this study, the couplets which were directly dealing with rain or which included elements indirectly associated with rain, such as clouds, mountains and thunders by 25 classical Turkish poets who lived in 16th century and whose names are included in the bibliography were identified by scanning the related diwan. Following this, the couplets which were identified were examined with subtitles of natural elements related to rain; elements associated with rain through analogy or metaphor; information on rain based on tradition, belief or experience; verses, hadiths and idioms on rain and other elements related with rain. The sample couplets included in the study to support the information given were classified and explained in accordance with the context of the article. This study, which was prepared with subtitles
\end{abstract}

Dr. Ö̆̆r. Üyesi, Ondokuz Mayıs Üniversitesi, Fen-Edebiyat Fakültesi, Türk Dili ve Edebiyatı Bölümü, Eski Türk Edebiyatı ABD (Samsun,Türkiye), syesilbag@hotmail.com, ORCID ID: oooo-ooo1-9219-3601 [Araştırma makalesi, Makale kayıt tarihi: 16.08.2021-kabul tarihi: 20.09.2021; DOI: 10.29000/rumelide.995450]

Adres | Address

RumeliDE Dil ve Edebiyat Araştırmaları Dergisi Osmanağa Mahallesi, Mürver Çiçeği Sokak, No:14/8 Kadıköy - İSTANBUL / TÜRKIYE 34714 e-posta: editor@rumelide.com

RumeliDE Journal of Language and Literature Studies Osmanağa Mahallesi, Mürver Çiçeği Sokak, No:14/8

Kadıköy - ISTANBUL / TURKEY 34714 tel: $+905057958124,+902167730616$

e-mail: editor@rumelide.com,

phone: +90 5057958124 , +90 2167730616 
created within the framework of the main title of rain, aims to show how classical Turkish literature poets perceived rain, which meanings and which elements they associated it with, and what kind of an emotion, thought and imagination world was created in the context of social and cultural life over the years.

Keywords: Classical Turkish literature, rain, bârân, matar

\section{Giriş}

Atmosferdeki su buharının yoğunlaşmasıyla oluşan ve yeryüzüne düşen yağışın sıvı durumunda olanı (TDK, 1998: II/2365) şeklinde tanımlanan yağmur için, klasik Türk şiirinde ekseriyetle Fasça eşanlamlısı olan bârân sözcüğü kullanılır. Az da olsa bazı beyitlerde yağmur ve matar sözcüğüyle karşılaşıldığı da olur.

Su ile ilgili olması hasebiyle anâsır-ı erba'adan olan yağmur, yine bu grup içerisinde yer alan denizle birlikte farklı tasavvurlarla şiirlerde en çok yer alan unsurdur. Yağmura değinilen beyitler; bahariye, nevruziyye, hazaniyye gibi ilkbahar ve sonbahardan bahseden nazım türleri içerisinde yer aldığı gibi bu türlere ait olmayan farklı nazım türleri ve biçimleri içerisinde de yer alabilmektedir.

Divan şiirinde her motif, birbirine bağlı unsurlar grubudur. Bu grubun içinden herhangi bir unsur zikredildiğinde öteki unsurların biri yahut birkaçı onunla birlikte bulunur. Bir motif, bu gibi unsurlarla ne kadar çok yüklü olursa ifade o ölçüde "cemiyetli" olma meziyetine sahip olur. Burada serbest, her şairce değişen çağrışım yerine, genellikle sınırları belirli ve her şair tarafından aynı unsurla ilgili olarak benzer çağgrışımlarla kurulan bir çağrışım ağının olduğu söylenebilir. (Akün, 2013: 155) Çalışmada üzerinde durulan yağmur konusu da incelenen beyitlerde bulut, dağ, gök gürülttüsü, gökkuşağı, nehir, rüzgâr gibi unsurların biri ya da birkaçıyla birlikte ve şairin hayal dünyasındaki bağlama göre beyitlerde yer alır. Yüzyıllar içerisinde geleneği oluşan, belirli kavramların belirli çerçeveyle ve metinlerde sözcüklerin bile belirli bir eksende yer almasına rağmen yine de şairlerin farklı bakış açılarına sahip oldukları da göz ardı edilemez.

Edebî eser, bir ferdin benliğini, kimliğini ve kişiliğini yansıtıyor gibi görünmekle birlikte sosyo-kültürel hayat alanının, tercih ve tepkilerinden meydana gelen özel bir kompozisyondur. Edebî eserin arkasında bir yazar, yazarın arkasında da sosyo-kültürel yapısıyla toplumun hayatı vardır. Her edebî eser, hangi sosyo-kültürel tabakanın estetik ihtiyaçlarına cevap verirse versin, o toplumun aynı zamanda tabiî ve düzenlenmiş çevre konusundaki bakışını, yorumunu ortaya koyar. (Tural, 1993: 3-4)

Tabiat, ihtiva ettiği unsurları ile sanatçların duygu, düşünce ve hayallerini anlatmakta tükenmez bir hazinedir. Şairler, zengin hayal güçleri ile tabiatı ve tabiat unsurlarını yorumlayarak eserlerinde malzeme olarak kullanmışlardır. Bu anlamda yağmur da Klasik Türk edebiyatı şairlerinin sevinçlerini, hüzünlerini anlatmakta vasıta olarak kullandığı bir temadır. Şairler, bu temadan bahsederken yağmurla ilişkili farklı unsurlara da temas etmiş; bu unsurlar üzerinden şahsî, toplumsal, kültürel ya da dini konulardaki birikimlerini dile getirmişlerdir. Bunun tespiti, ele alınan temanın ilişki ağının tespiti açısından önemlidir. Bu amaçla aşağıda inceleme sonunda oluşan, yağmurla ilgili mefhumların gösterildiği bir şema yer almaktadır. Şema, aynı zamanda makalenin de planını özetlemekte ve elde edilen verileri sistematik ve sınıflandırmalı bir şekilde ortaya koymaktadır.

\begin{tabular}{r|l} 
Adres & Address \\
RumeliDE Dil ve Edebiyat Araştırmaları Dergisi & RumeliDE Journal of Language and Literature Studies \\
Osmanağa Mahallesi, Mürver Çiçeği Sokak, No:14/8 & Osmanağa Mahallesi, Mürver Çiçeği Sokak, No:14/8 \\
Kadıköy - İSTANBUL / TÜRKIYE 34714 & Kadıköy - ISTANBUL / TURKEY 34714 \\
e-posta: editor@rumelide.com & e-mail: editor@rumelide.com, \\
tel: +90 505 7958124, +90 216773 o 616 & phone: +90 505 7958124, +90 216773 o 616
\end{tabular}




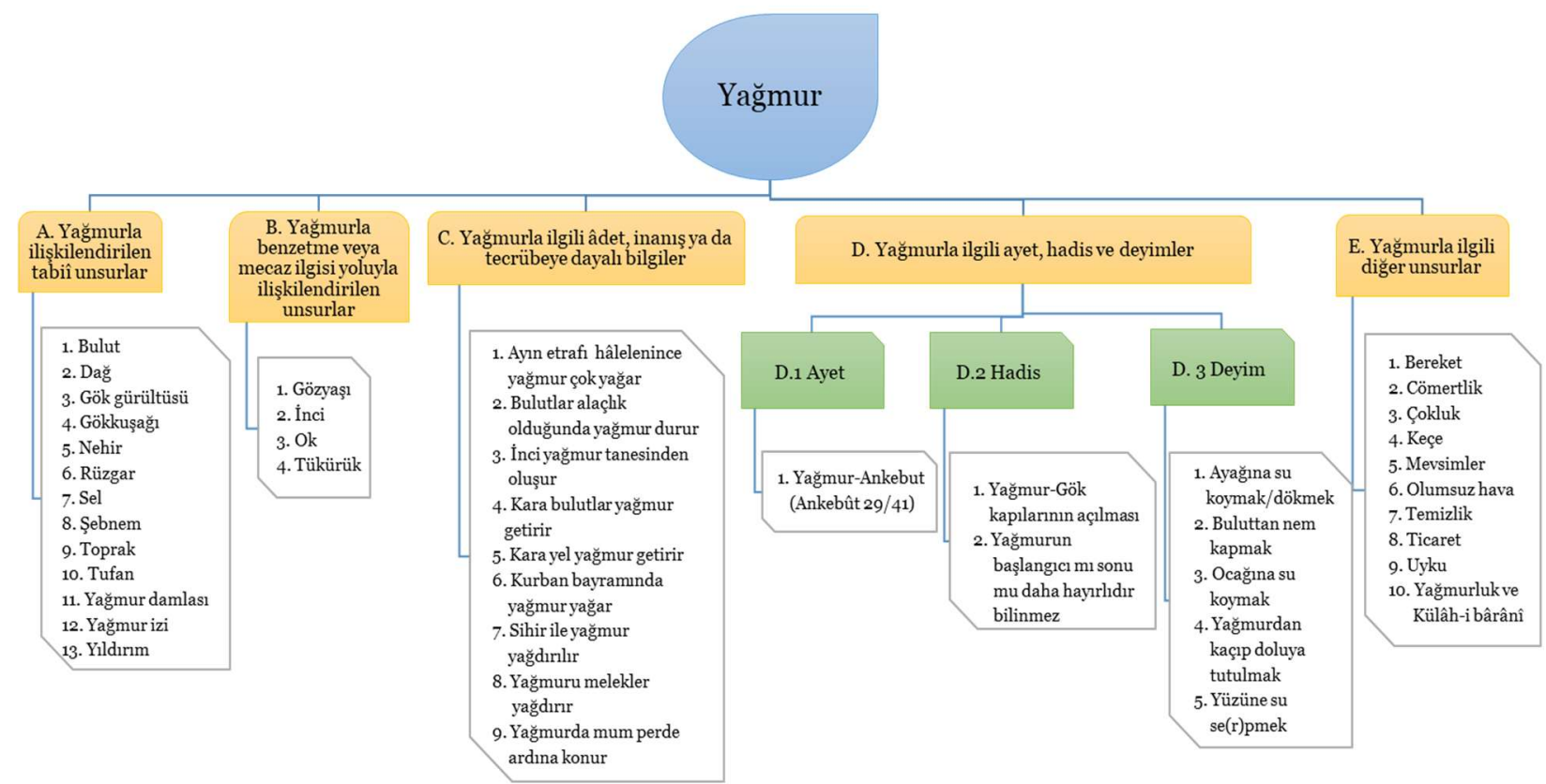

\section{A. Yağmurla ilişkilendirilen tabiî unsurlar}

\section{Bulut (Ebr, Sehâb, Gamâm)}

Yağmurdan bahsedilen yerlerde sıklıkla yer alan bulut için beyitlerde daha çok Farsça ebr sözcüğünün kullanıldığı görülmektedir. Az da olsa bulut ve sözcügün Arapçası olan sehâb, nadiren de gamâm kelimelerine de rastlanmaktadır.

Gökteki bulutlar, gündelik hayatı ve iklim şartlarını belirleme bakımından insanların görüp yorum geliştirdikleri tabiat unsurlarındandır. Özellikle şairler, eserlerinde yer verdikleri tabiat tasvirlerine bir şekilde bulut veya bulutla ilgili tasavvurlarını da dâhil etmişlerdir. (Şentürk, 2017: II/300)

Klasik şiirde bulutların ağlama sembolü olarak kullanıldığı söylenebilir. Söz gelimi Hayretînnin aşağıdaki beyitlerinde bulutun âşığın dertli hâline üzüldüğü ve bu yüzden ağlayıp gözyaşları döktüğü dile getirilmektedir.

Dâne-i bârân degüldür yeryüzine dökülen

Derd ile göklerde olmışdur bulutlar eşkbâr

(Hayretî, K. 9/78) ${ }^{2}$

[Yeryüzüne dökülen yağmur tanesi değildir. Bulutlar, dert ile yağmur gibi gözyaşlarını yă̆dırmaktadır.]

2 Örnek şiirlerin künyeleri beyitlerin/bentlerin altında şairin adı yahut mahlasından sonra şekil bilgisi, şiir numarası, beyit ya da bent numarası şeklinde gösterilmiştir.

Şiirlerin künyesinde nazım şeklini gösteren kısaltmaların açılımları da şu şekildedir: Gazel: G., Kaside: K., Mu'aşşer: Mua., Murabba: Mur., Mukatta: Muk.

Örnek şiirlerlerde transkripsiyon harflerinin tamamı kullanılmamıș; uzun ünlüler, 'ayın, nazal nun işaretleri kullanılmıştır. Beyitlerde bazı düzeltmeler yapılmış, bazı beyitler de farklı unsurları vurgulamalarından dolayı tekrarlanmıştir. 
Şol kadar âh ideyin şol deñlü yaşlar dökeyin

Acısun deryâ-yı 'ummân ebr ü bârân ağlasun

$$
\text { (Hayretî, G. 378/2) }
$$

[O kadar âh edip gözyaşı dökeyim ki okyanuslar hâlime acısın; bulut ve yağmur (benim için) ağlasın.]

Âşığın ettiği âhlar, siyah bir duman şeklinde gökyüzüne yükselir ve rengi dolayısıyla Muhibbî, Behiştî ve Za‘îfî’nin aşağıdaki beyitlerinde olduğu gibi, yağmur bulutlarına benzetilir.

İy Muhibbî gözlerüm bârân-ı eşki yağdurur

Anuñ içün dûd-ı âhum üstine bulutdur

(Muhibbî, G. 940/7)

[Ey Muhibbî, gözyaşı yağmurlarını yağdırabilmesi için âhımın dumanı gözlerimin üstünde buluttur.]

Kimüñ kim ebr-veş âhı sipihre reh-güzâr itmez

Vücûdı 'arsasın bârân-ı rahmet sebze-zâr itmez

(Behiştî, G. 205/1)

[Kimin âhı, bulut gibi gökyüzünden geçmezse rahmet yağmuru, vücudunu yeşillendirmez.]

Katre katre dökülen eşkile hicrüñde bu âh

Biri bârân-ı cihân oldı biri ebr-i siyâh

$$
\text { (Zaî̂fî, G. 275/1) }
$$

[Senin ayrılığın yüzünden damla damla dökülen gözyaşı ve çekilen bu âhtan biri dünyayı sele veren yağmur, diğeri bulut oldu.]

Gelibolulu Mustafa Âlî’nin aşağıdaki beytinde olduğu gibi, siyah rengi dolayısıyla bulut ile sevgilinin kaşları arasında benzerlik ilgisi kurulur. Buluta benzeyen sevgilinin kaşları çatıldığında bunu gören âşı̆̆ın gözyaşları yağmur gibi yağar.

Ol ki pür-çîn ola gözyaşları bârâna döner

Ebr-i rahmet mi nigârâ niçe ebrûdur bu

(Gelibolulu Mustafa Âlî, G. 1173/4)

[O (sevgili) kaşlarını çattığında (âşığın) gözyaşları yağmur gibi boşanır. Ey sevgili (kaşın) rahmet bulutu mudur, nasıl kaştır bu?]

Behiştî̀nin aşağıdaki beytinde kararan kaş ifadesiyle de yağdığında felaketlere sebep olan yağmurların kastedildiği ve bu durumun belâ bulutu olarak nitelendirildiği görülmektedir.

Sîne sahrâsına yağdırmağa bârân-ı gamı

Kıt‘a-i ebr-i belâdur kararan kaş degül

(Behiştî, G. 315/2)

[Sine sahrasına gam yağmurunu yağdıran, kararmış kaş değil, belâ bulutunun parçasıdır.]

Bazen de memduhun düşmanlarmın gözyaşları yağmura benzetilir. Nitekim Mesîhînin aşağıdaki beytinde gök gürültülü bir yağmur tasviri yapıldığı görülmektedir. Bu tasvirde, memduhun atının kişnelemeleri gök gürültüsüne, yağmur ise gök gürültüsüne benzeyen bu sesten korkan düşmanların gözyaşlarına benzetilmiştir.

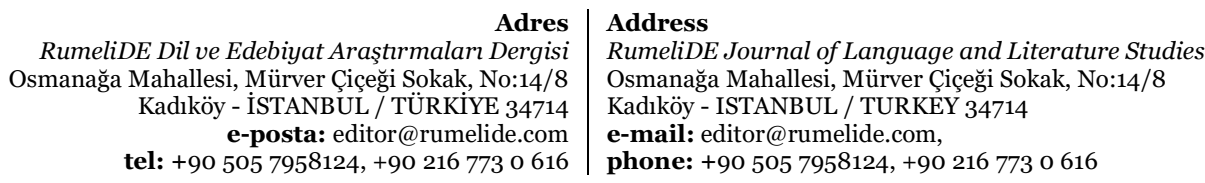


Yağmur gibi yağar gözi yaşı 'adûlaruñ

Esbüñ kaçan ki kişneye altuñda ra'd-vâr

(Mesîhî, K. 17/ 29)

[Atın altında gök gürültüsü gibi kişnediğinde, düşmanların gözyaşı, yağmur gibi yağar.]

Nev'î’nin “Güneş, besleyip yetiştirdiğinin ayaklar altında zelil olduğunu görmek istemediğinden, yağmur bulutlarını yüzüne perde eder.” denen aşağıdaki beyitte olduğu gibi kimi zaman güneş ya da ayın önünü kapatan bulut; perde, örtü, yelpaze gibi varlıklara benzetilerek kullanılır.

Diler ki görmeye perverdesin ayaklarda

Hicâb ider yüzine mihr ebr-i bârânı

(Nevî̀, K. 51/7)

Aşağıdaki beyitte de gökyüzünde topak topak bulunan beyaz bulutların pamuğa benzetildiği, bu benzetme üzerinden ölmek üzere olan ağır hastalara pamukla su verilmesi âdetine telmih yapıldığı görülmektedir.

Hastelendi görüp ey gül lebüñi gonca-i bâg

Tamzurur penbe ile ebr-i bahâr ağzına su

(Mostarlı Ziyâî, G. 380/4)

[Ey gül; gonca, dudağını görüp (kıskançlığından) hastalandığı için bahar bulutu, pamukla ağzına su damlatır.]

Ebr ü bârân sanma gökde kim Sehâbî hastenüñ

Penbe ile ağzına su tamzurur hem-vâre çerh

(Sehâbî, G. 47/6)

[Sehâbî, gökyüzündekini bulut ve yağmur zannetme; gökyüzü, pamuk ile hastanın ağzına durmadan su damlatmaktadır.]

Ölüm döşeğinde olan bir kişiye şeytanın musallat olup onun imanını çalmak için her türlü hileye başvurduğuna inanılır. Şeytanın hilelerinden biri de ömrünün son demlerini yaşayan ve susuzluk çeken kişiye imanı karşılığında su vereceğini söyleyerek insanı kandırmasıdır. Bu sebeple ölmek üzere olan kişilerin ağzına su damlatılır veya pamukla su verilir. (Özkan, 2007: 363)

Celîlı̂nnin gözyaşları ile yağmurlar arasında benzerlik ilişkisi kurduğu aşă̆ıdaki beyitte bulutların yağmur suyunu denizlerden aldığı bilgisine de yer verildiği görülmektedir.

Gözüm san ebr-i bârân-ı belâdur

Ki deryâ-yı gamuñdan oldı fâ’iz

(Celîlî, G.173/4)

[Gözüm, sanki senin gam denizinden taşan belâ yağmuru yağdıran bir buluttur.]

Sevgilinin saçının buluta benzetildiği aşağıdaki beyitlerde, âşı̆̆ın gözyaşları da yağmur şeklinde değerlendirilmiştir. Bir yandan da ilk beyitteki katre ile deniz arasındaki tezat dikkati çekmektedir. 
Havâ-yi ebr-i zülfi ile yaşum bârânınuñ Zâtî

Deñizden katresin vasf eylesem dünyâyı ağladam

(Zâtî, G. 908/7)

[Zâtî, (sevgilinin) buluta benzer zülfüne tutkunluğum ile döktüğüm yağmur gibi gözyaşlarımın denizden damla misali olan ufacık bir kısmını tarif etsem (bu tutkunluğa) dünya ağlar.]

Kaplayup zülfüñ sehâbıyla yüzüñ nevrûzını

Dem-be-dem eşkümi sensin anda bârân eyleyen

(Zaî̂fî, G. 248/5)

[(Ey sevgili) bahar yüzünü bulut saçınla kapattığından gözyaşlarımı daima yağmur gibi yağdıran sensin.]

Kara yağmur bulutları, gökyüzünü kapladığında yağmur yağması, tabiî bir olaydır. Şair, bu tabiî hadiseden hareket ederek güneşe benzeyen sevgilinin yüzünün, siyah rengi dolayısıyla buluta benzeyen saçları tarafından örtüldüğünü ifade etmektedir. Bu şekilde güneşin önünün bulutla çevrilmesi gerçekleşmiş olmaktadır. Geriye yağmurun yağması kalmaktadır ki o da sevgilinin yüzü üstüne düşen saçlarını gören âşığın aşkının huruşa gelip gözyaşlarını akıtmasıyla tamamlanır.

Düşmeyince yüzüñe zülfüñ bu çeşmüm ağlamaz

Gün bulutlu olmayınca nicesi bârân yağar

(Mesîhî, G. 92/3)

[Gökyüzünde bulut olmadan nasıl yağmur yağmazsa senin de yüzüne saçın düşmezse gözlerim gözyaşları dökmez.]

Yağdırdığı su ile yeryüzündeki canlılara hayat vermesi bakımından bulutlar, sık sık cömertlikle ilişkilendirilir. Aşağıdaki beyitte bulutların cömertlik eli, yağan yağmurların da gümüss para şeklinde görüldüğü bir tasavvura yer verilmiştir.

Ebr yağdurmaz yire vaktinde ol denlü matar

Şöyle kim dest ile ehl-i fakra sîm eyler nisâr

(Usûlî, K. 3/29)

[Eliyle fakirlere o kadar gümüss yağdırır ki bulutlar bile o nispette yağmur yağdırmaz.]

Yüce dağların yüksek kesimleri, genellikle bulutlarla çevrili olur. Hüsn-i talil sanatının dikkat çektiği aşağıdaki beyitte dağ başındaki bulutların kara renkte olması, Ferhad'ın yasını tutmaları sebebine bağlanmıştır.

İhâta eyleyen kûhsârı sanma ebr-i bârândur

Kara tonlar giyüp tutar belâ Ferhâd'ınuñ yasın

(Behiştî, G. 408/2)

[Dağı çevreleyeni yağmur bulutları zannetme; dağ, karalara bürünmüş belâ Ferhâd’nın yasını tutmaktadır.]

Âşık Çelebi'nin bir kasidesinden alınan aşağıdaki beyitte memduhun adaletli yönetimi altında fitnenin uykuda olduğu, cihanın rahata erdiği ve adalet bulutunun onur, haysiyet gibi insanlığa şeref bahşeden erdemleri yağmur gibi yağdırdığı ifade edilmektedir.

\begin{tabular}{|c|c|}
\hline & \\
\hline RumeliDE Dil ve Edebiyat Araştırmaları De & E Journal of Language and Literature Studie \\
\hline smana ğa Maha & Mahallesi, Mürver Çiçeği Sokak, No:14/8 \\
\hline Kadıköy - & ISTANBUL / TURKEY 34714 \\
\hline tel: +9050 & $\begin{array}{l}\text { e-mail: editor@rumelide.com, } \\
\text { phone: +90 505 7958124, +90 } 216773 \text { o } 616\end{array}$ \\
\hline
\end{tabular}


Gaflet uykusunda fitne hâb-ı râhatda cihân

Ebr-i 'adli 'âleme yağdurdı bârân-ı şeref

(Âşık Çelebi, K. 8/12)

[Fitne, gaflet uykusunda; cihân, rahat uykusundadır. Onun adalet bulutu, cihana şeref yağmurları yağdırdı.]

Aşağıdaki beyitte yine bir memduhun adaletli yönetiminde herkesin mutlu olduğu, kimsenin mutsuz olup gözyaşları dökmediği, gözyaşlarını dökenin sadece bulut olduğu dile getirilmektedir.

Ebr-i bârândur zamânında meger giryân olan

Şems-i 'adlinden güler cümle gülistân-ı cihân

(Taşlıcalı Yahyâ Bey, K. 2/23)

[Onun adalet güneşinden dünya gül bahçesindekilerin hepsi güler. Devrinde ağlayan, sadece yağmur bulutudur.]

Şehre su getirirken suyu çeşitli engellerden aşırmak için yapılan su kanallarına su kemeri denir. Aşağıdaki beyitte su kemerlerinin yan yana dizilmiş kavisli yapısının uç uca dizilmesi ile deve kervanına; suyu nakletmesi ile de yağmur bulutlarına benzetildiği görülmektedir.

Deve katarına beñzer kemerlerin gördüm

Didüm ki yeryüzinüñ budur ebr-i bârânı

(Taşlıcalı Yahyâ Bey, K. 5/11)

[(Su yollarının) deve kervanına benzer kemerlerini gördüm. Yeryüzünün yağmur bulutu budur, dedim.]

Taşlıcalı Yahyâ'nın bir beytinde bulutların rüzgârın hükmüne râm olup savrulması, şekilden şekle girip diyar diyar dolaşmaları; mantıklı düşünemeyen çocukların tavırlarına benzetilmiş ve insanın rüzgârın önündeki bulutlar misali arzularına esir olmaması tavsiyesinde bulunulmuştur.

Hevâña tâbi‘ olup ebr-i nev-bahâr gibi

Nukûş-ı ‘âleme olma sabî gibi meyyâl

(Taşlıcalı Yahyâ Bey, K. 20/5)

[İlkbahar bulutu gibi isteklerine uyup âlemin nakışlarına çocuk gibi çok arzulu olma.]

\section{Dă̆ (Kûh, Kûhsâr, Cebel)}

Dağlar, ısınan havanın yamaç boyunca yükselerek soğuyup yoğunlaşması sebebiyle nispeten yağmurların çok yağdığı mekânlardandır. Gürül gürül yağan yağmur sularının dă̆ eteklerindeki toprakla birlikte boz bulanık düz alanlara doğru akıp pınarlara karışması, yağmurlarla ilgili değinilen hususlardandır. Nitekim Zâtî̀nin aşağıdaki beytinde dağ yamaçlarından vadilere doğru bulanık şekilde akan yağmur suları ile âşığın gözünden akan kanlı gözyaşları arasında bulanık olma açısından ilgi kurulduğu görülmektedir.

Kûhsâr-ı dilde bârân-ı belâ mı yağdı kim

Kan bulanık ey sirişk-i hûn-feşân cûyuñ senüñ

(Zâtî, G. 743/3)

[Ey kanlar saçan gözyaşı, gönül dağında bela yağmurları yağdığı için mi senin ırmakların kan gibi bulanık akmaktadır?]

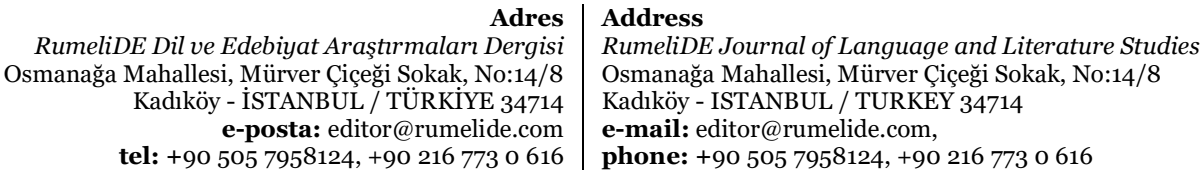


Bahar mevsiminde ağaçsız, dik yamaçlı dağlık yerlerde yağan yağmurlar, sellere; seller de yamaçlarda toprak kaymalarına, dağ eteklerinde derin çatlaklara sebep olabilmektedir. Aşağıdaki beyitte şiddetli yağmurların dağ eteklerinde neden olduğu bu tahribat ile âşı̆̆ın gözyaşlarının akmasına sebep olan gönlündeki yaralar arasında ilgi kurulmaktadır.

Yaralar açsa ne tañ sîneme seylâb-ı sirişk

Olsa bârân nite kim çâk ide kûhsâr eteğin

(Muhibbî, G. 2491/4)

[Gözyaşlarımın sel suları sineme yaralar açsa şaşılır mı? Zira yağmur, dağ eteklerinde yarıklar oluşturur.]

Bahar mevsiminde yağan yağmurlar, bir yandan tahribata sebep olurken diğer yandan da dağların yağmur alan cephelerinin yeşillenmesini sağlar. Bu sebeple dağlara uzaktan bakıldığında dağ etekleri yemyeşil görünür.

Akıdur dürr ü cevâhir yine bârân-ı bahâr

Anuñ içün görinür bir yaña kûhsâr sebz

(Muhibbî, G. 1267/4)

[Bahar yağmurları yine inci, mücevher akıttığı için dağın bir yanı yeşil görünmektedir.]

Zirveleri bulutlarla çevrili yüce dağlar ve bu dağlık yerlerde yağan yağmurlar, sıradan bir tabiat hadisesi iken şair muhayyilesinde dağ, bir insan; bulutlar, bu insanın çözerek serbest bıraktığı saçları, yağmurlar da dağların âşı̆̆ın hâline üzüldüğü için döktüğü gözyaşları olarak değerlendirilmiştir.

Görinen taglar başında ebr ü bârân sanmañuz

Taglar saçın çözüp ben hasta içün ağlar

(Zâtî, G. 163/2)

[Dağların zirvelerindekini bulut ve yağmur sanmayın. Zira dağlar saçını çözmüş, hasta olan bana ağlamaktadır.]

Aşağıdaki beyitte bahar bulutlarının sardığı dağ zirvesi, manastır içinde siyah şala bürünmüş bir ruhban şeklinde tasavvur edilmiştir. Hristiyanlara ait ibadet yerleri olan manastırların genellikle insanlardan uzak, dağ etekleri gibi yerlerde yapılması, bulut ile dağ arasındaki mekân ilişkisinin manastır ile dă arasında da kurulduğunu göstermesi açısından önemlidir.

Görindi ebr-i bahârî içinde kulle-i kûh

Siyâh şâlla deyr içre nitekimruhbân

(Bursalı Rahmî, K. 8/3)

[Bahar bulutları içindeki dağın zirvesi, manastır içindeki siyah şallı ruhban gibi görünmektedir.]

Dağlar, bulutların mekânı olma dışında farklı sebeplerle insanların kaçıp saklandıkları yer olma özelliğine de sahiptir. Nitekim aşağıdaki beyitte memduhun düşmanının dağlara kaçtığından bahsedilmektedir.

\begin{tabular}{r|l} 
Adres & Address \\
RumeliDE Dil ve Edebiyat Araştırmaları Dergisi & RumeliDE Journal of Language and Literature Studies \\
Osmanağa Mahallesi, Mürver Çiçeği Sokak, No:14/8 & Osmanağa Mahallesi, Mürver Çiç̧̧ Sokak, No:14/8 \\
Kadıköy - İSTANBUL / TÜRKIYY 34714 & Kadıköy - ISTANBUL / TURKEY 34714 \\
e-posta: editor@rumelide.com & e-mail: editor@rumelide.com, \\
phone: +90 505 7958124, +90 2167730616
\end{tabular}


Gazâda esb-i sabâ-sür'atüñle irişicek

Bulut gibi kaçuban taglara düşer a‘dâ

$$
\text { (Taşlıcalı Yahyâ Bey, K. 12/29) }
$$

[Sen, savaş meydanında sabah yeli hızındaki atınla hücum edince, düşmanlar bulut gibi kaçarak dağ yolunu tutar.]

\section{Gök gürülttüsü (Ra'd)}

Gök gürültüsü, şimşek çaktıktan ya da yıldırım düştükten sonra duyulan gürültüdür. Elektriğin boşalması sırasında ısınan havanın birdenbire genişlemesinden meydana gelen bu olayda elektrik boşalımı yakın yerde olmuşsa gök gürlemesi kısa sürer, patlamaya benzer bir ses olur; boşalım uzakta olmuşsa gök gürlemesi, uğultu olarak duyulur. (İzbırak, 1964: 141)

Yağmur ve yıldırıma yer verilen çoğu yerde bu unsurlarla ilgili olarak gök gürültüsüne de yer verildiği görülmektedir. Klasik Türk edebiyatı şairleri gök gürültüsünü genellikle aşk derdi ve bahtından şikâyeti sebebiyle âşı̆̆ın nâle, efgân ve âh u zâr ederken çıkardığı seslere benzetmişlerdir.

Âhumı ra'd eşkümi bârân ider her bâr çarh

Yeridür ger zâr zâr iñlese gaddâr çarh

(Behiştî, G. 72/1)

[Felek, her defasında âhımı gök gürültüsü, gözyaşlarımı yağmur eder, (bana bu çektirdiklerinden dolayı) zâlim felek kendisi de ağlayıp inlemeye müstahaktır.]

Degül ra‘d u bârân görüp hâl-i zârum

Felekler melekler baña ağlar acır

(Mânî, K. 1/14)

[(Görüp duydukların) gök gürültüsü ve yağmur değildir. İçler acısı hâlimi görünce gökyüzünün ve meleklerin bana acıyı ağlamalarıdır.]

Nâle ra'd u âhum oldı başum üstinde gamâm

Dîdelerden kim döker âh ile bârân uşta ben

(Muhibbî, G. 2565/5)

[İnlemelerim, gök gürültüsü; ettiğim âhlar başım üstünde bulut oldu. Âh edip gözlerinden yağmur gibi yaşlar döken (birisini görürsen) işte o benim.]

Görüp işitdügüñ sanma ki dem dem ra'd ü bârândur

Bulutlardur elinden dâyimâ ağlar figân eyler

(Zâtî, G. 359/4)

[Ara ara görüp duyduğunu yağmur ve gök gürültüsü zannetme; (onlar, âşığın hâline üzülmeleri sebebiyle) bulutların ağlayıp inlemeleridir.]

Gök gürültüleri, şair muhayyilesinde bazen hutbe okuyan belki celalli bir şekilde vaaz ve nasihatte bulunan bir vâizin sesine de benzetilmiştir.

Minber-i ebr üzre çıkmış ra‘d tîg-i berk ile

Hutbe okur tîr-i rahmetdür yağan bârân degül

(Zâtî, G. 824/)

[Gök gürültüsü, şimşek kılıcıyla bulut minberine çıkmış hutbe okumaktadır. Yağan; yağmur değil, rahmet okudur.]

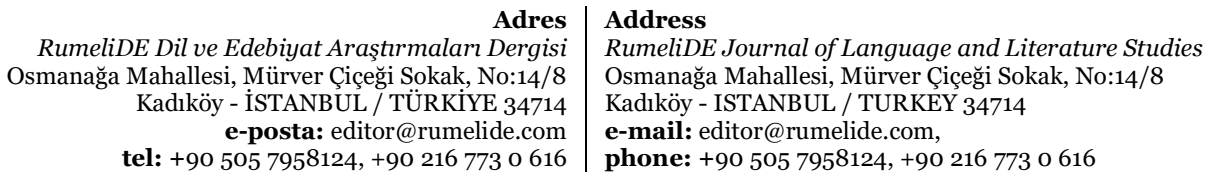

tel: $+905057958124,+902167730616$

: editor@rumelide.com

phone: +90 $5057958124,+902167730616$ 
Hz. Peygamber’in torunu Hz. Hüseyin, Kerbela'da susuz bırakılmış ve şehit edilmiştir. Bu acıklı durum, Müslümanların içini kanatan bir acı olarak hafızalara ve gönüllere kazınmıştır. Aşağıdaki beyitte buluttan dökülen yağmurların ve yağmur yağarken duyulan gök gürültülerinin Hz. Hüseyin'e duyulan üzüntü sebebiyle olduğu dile getirilmektedir.

Berk oldı yine bir çakım âteş bu gussadan

Ağlar sehâb u ra‘d ider efgân yâ Hüseyin

(Hayretî, K. 4/15)

[Bu kederin (yanında) şimşek, yine bir çakımlık ateş oldu; Ey Hüseyin, (bu keder sebebiyle) bulut ağlar ve gök gürültüsü feryât eder.]

Gök gürültüsünün farklı hayallerle kullanıldığında da sıklıkla ağlama ve inleme sesleri ile irtibatlandırıldı̆̆ı görülmektedir.

Tâze sebz olsun diyü cânâ cemâlüñ gülşeni

Ra‘d-veş âh eyleyüp nîsân-ı bârân-dîdeyin

(Muhibbî, G. 2675/4)

[Ey sevgili! Cemâlin gülşeni yemyeşil olsun diye gök gürültüsü gibi âh eyleyip nisan yağmuru gibi gözyaşı dökmekteyim.]

Ra‘d iñler ebr ağlar dâyimâ Ferhâd içün

Her yaña cûlar akar kûhsâruñ giryesi

(Muhibbî, G. 3268/3)

[Ferhad için daima gök gürültüleri, inler; bulutlar ağlar. Dağın gözyaşları olan ırmaklar da her yana akar.]

Sehâb u ra'd çemen hâline terahhum idüp

Birisi ağlayup eyler birisi âh u efgân

(Sehâbî, K. 7/6)

[Bulut ve gök gürültüsü çimenliğin hâline acıdığından biri ağlar, diğeri de âhlar, feryatlar eder.]

Atın kişnemesi, bülbülün ötmesi veya su değirmeninin çıkardığı sesler gibi kimi yüksek seslerin de yine beyitlerde gök gürültüsüne benzetilerek kullanıldığı görülmektedir.

Yağmur gibi yağar gözi yaşı 'adûlaruñ

Esbüñ kaçan ki kişneye altuñda ra‘d-vâr

(Mesîhî, K. 17/ 29)

[Bindiğin atın gök gürültüsü gibi kişnediğinde düşmanlarının gözyaşı, yağmur gibi yağar.]

Ra‘d-ı bülbül na'rasıdur kirm-i şeb-tâb aña berk

Eylemişdür gülşeni bârân-ı şeb-nem nûra gark

(Gelibolulu Mustafa Âlî, G. 650/1)

[Bülbülün gök gürültüsünü (andıran ötüşü) narasıdır, ateş böcekleri şimşekleridir. Şebnem yağmurları, gül bahçesini apaydınlık yapmıştır.]

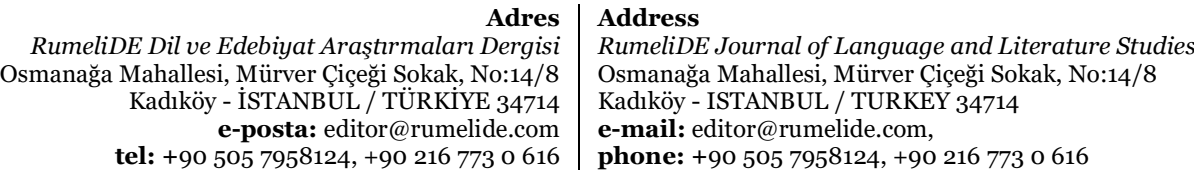

tel: +90 505 7958124, +90 2167730616 
Bûstân-ı çarhda tôlâbdur kavs-i kuzah

Na'ra-i ra‘d anuñ efgânı suyı bârândur

(Meâlî, G. 248/4)

[Gökkuşağı, felek bostanında su değirmenidir. Gök gürültüsü bu değirmenin çarklarının dönerken çıkardığı feryadı andıran sesleri, yağmur da suyudur.]

\section{Gökkuşağı (Kavs, Kavs-ı kuzah)}

Gökkuşağı, yağmurdan sonra havada asılı kalan su zerreciklerine yansıyan güneş ışınlarının kırılması sonucu meydana gelen bir tabiat olayıdır. Su damlacıkları, güneş ışığının çarptığı damlacıkta prizma etkisi göstererek farklı renklere sahip bir kuşak şeklinde ortaya çıkar. Gökkuşağındaki bu farklı renkler, havadaki su damlacıkları büyükse daha belirginken, küçük su damlacıklarında daha soluk görülür.

Işığın yağmur damlaları içerisinde kırılmasından, yansımasından oluşan gökkuşağı, hava küredeki ışık olaylarından biridir. Gökkuşağında mor, lacivert, mavi, yeşil, turuncu, sarı, kırmızı renkler görülür. Yeryüzünde yarım çember şeklinde görülen gökkuşağı, uçaktan bakıldığında tam bir çember şeklinde görülür. (İzbırak,1964: 141)

Aşağıdaki beyitte dünya, farklı kokularla donanmış çiçeklerin olduğu bir bahçeye; gökkuşağı, bu bahçedeki değirmene; gök gürültüsü, değirmen çarkının dönerken çıkardığı seslere; değirmenin suyu da yağmur suyuna benzetilerek yağmurlu bir hava atmosferi oluşturulmuştur.

Bûstân-ı çarhda tôlâbdur kavs-i kuzah

Na'ra-i ra‘d anuñ efgânı suyı bârândur

(Meâlî, G. 248/4)

[Gökkuşağı, felek bostanında su değirmenidir. Gök gürültüsü bu değirmenin çarklarının dönerken çıardı̆̆ feryadı andıran sesleri, yağmur da suyudur.]

Bir yerde gökkuşağının ortaya çıması için yağmur yağması gerekir. Bu anlamda yağmur ile gökkuşağı, sebep-sonuç ilişkisiyle birbirine bağlıdır. Aşağıdaki beyitte gökkuşağı ile sevgilinin kaşı arasında kavisli şekle sahip olma açısından benzerliğin kurulduğu görülmektedir. Bu benzerlik ilişkisi üzerinden söylenmek istenen, âşığın yağmura benzeyen ağlamasının sebebinin sevgilinin gökkuşağına benzeyen kaşını görmesi olduğudur.

Nite kim yağmur olur kavs-ı kuzah olsa 'ayân

Zâtîyâ yaşumı her dem benüm ol kaş akıdur

(Zâtî, G. 234/5)

[Bir yerde gökkuşağı görünse orada yağmur yağar. Ey Zâtî, her zaman gözyaşlarımın akmasının sebebi de sevgilinin gökkuşağına benzeyen kaşlarıdır.]

Beyitlerde kavisli yapısından dolayı gökkuşağının yaya, yağmurun ise oka benzetildiği kullanımlara sıklıkla rastlanır.

Yağmur gibi yağdurmağa gam okını baña

Teşbîh ider kavs-i kuzah kendüyi yaya

(Mesîhî, G. 210/5)

[Gökkuşağı, bana gam oklarını yağmur gibi yă̆dırmak için kendini yaya benzetir.]

\begin{tabular}{|c|c|}
\hline & \\
\hline RumeliDE Dil ve Edebiyat Araştırmaları De & E Journal of Language and Literature Studie \\
\hline smana ğa Maha & Mahallesi, Mürver Çiçeği Sokak, No:14/8 \\
\hline Kadıköy - & ISTANBUL / TURKEY 34714 \\
\hline tel: +9050 & $\begin{array}{l}\text { e-mail: editor@rumelide.com, } \\
\text { phone: +90 505 7958124, +90 } 216773 \text { o } 616\end{array}$ \\
\hline
\end{tabular}


Ceng ider 'işkuñ yolında âsmân ile zemîn

Sanki bârân tîrdür kavs-i kuzah ey meh kemân

(Meâlî, G. 177/6)

[Ey sevgili, senin aşkın uğruna gökyüzü ile yeryüzü savaş hâlindedir. Bu savaşta yağmurlar sanki ok, gökkuşağı da yaydır.]

Kavsümüz yağmur gibi a‘dâya peykân yağdurur

Tîgumuz berk urdıgınca nûr-ı îmân yağdurur

(Taşlıcalı Yahyâ Bey, Mua. 11-2/2)

[Yayımız, düşmanlara yağmur gibi ok yağdırır. Kılıcımız, şimşek çakar gibi parıldayınca iman nuru yağdırır.]

\section{Nehir}

Yağmur, sadece canlıların hayatta kalması, büyüyüp gelişmesi için değil, nehirler için de suyun istenen belirli seviyede kalmasına yardım eden unsurlardandır. Aşağıdaki beyitte Nil Nehri’nin yağmur sularıyla beslendiği, yağmur yağmadığı takdirde su seviyesinde sıkıntı yaşanacağı dile getirilmektedir.

Lâ-cerem bir gün zemîn-i huşk olur deryâ-yı Nîl

Menba'indan yağmasa bir nice dem bârân eger

(Bâkî, K. 13/8)

[Kaynağından uzun bir süre yağmur yağmasa Nil Nehri, şüphesiz kurak bir mahal olur.]

Ekvator yakınlarından kuzeye, Akdeniz’e akan Nil, kaynağının neresi olduğu, diğer büyük nehirlerin tersine neden güneyden kuzeye aktığı ve yazın aylarca yağmur yağmadığı halde neden yaz sonunda taştığı meseleleriyle ilgili olarak yüzyllarca insanlar için gizemlerle dolu bir nehirdi. 1862 yllında İngiliz kâşif John Hanning Speke, Nil’in Uganda'daki Victoria Gölü’nden kaynaklandığını buldu; ancak yaz sonundaki taşkınların nedeni hâlâ çözülememişti. Yıllar sonra Nil’in yaz aylarında sularının azalmamasının hatta taşkınlar olmasının başlıca nedeninin Nil’in kaynağına yakın bir bölgede bulunan Etiyopya'daki şiddetli yaz yağmurları olduğu anlaşıldı. (Temel Britannica, 1988: XIII/85-86)

\section{Rüzgâr (Bâd)}

Rüzgâr ile âşı̆ın âhı arasında bir hava hareketi olma, titreme, esme, eserken ses çıkarma gibi hususiyetlerle benzerlik ilişkisi kurulur. (Kurnaz, 1996: 510) Yağmurlardan önce genellikle rüzgâr çıar. Yağmurun habercisi olan bu rüzgârlar, gökyüzünde yağmur bulutlarını hareket ettirerek yağmurun yağmasinda rol oynar.

Sevgili, âşığına karşı gaddardır, gamze okları ile onun kalbini yaralar, ona iltifat etmez ya da en iyi hâlde aşağıdaki beyitte olduğu gibi âşığına güler yüz göstermeyip tatlı bir söz söylemeden karşısında âdeta dili bağlı bir şekilde durur. Doğal olarak sevgilinin bu hareketi, âşı̆̆ı kederlendirir. Bu keder neticesi olarak âşık, âhlar eder. İçine düştüğü bu duygu yoğunluğu ile bir yandan da âşığın gözyaşları yanaklarından süzülmeye başlar. Beyitlerde bir tür hava hareketi olan âh ile rüzgârın işlevce ayniyet kazandığı ve âşığın önce âhlar edip ardından ağlaması ile rüzgârların çıkıp ardından yağmur yağması arasında bir ilgi kurulduğu görülmektedir.

\footnotetext{
\begin{tabular}{r|l} 
Adres & Address \\
RumeliDE Dil ve Edebiyat Araştırmalar Dergisi & RumeliDE Journal of Language and Literature Studies
\end{tabular} Osmanağa Mahallesi, Mürver Çiçeği Sokak, No:14/8 Osmanağa Mahallesi, Mürver Çiçeği Sokak, No:14/8

Kadıköy - İSTANBUL / TÜRKIYE 34714 Kadıköy - ISTANBUL / TURKEY 34714 e-posta: editor@rumelide.com e-mail: editor@rumelide.com, tel: +90 505 7958124, +90 2167730616 phone: +90 505 7958124, +90 2167730616
} 
Gül gibi gülmez açılmaz gonca-veş dil bestedür

Bâd-ı âhum isteyüp bu dîdeden bârân umar

(Muhibbî, G. 425/4)

[Gönül, gül gibi açılıp gülmez, gonca gibi ağzı bağlıdır. Âhlarımın rüzgârının çıkmasını ve bu gözden yağmur gibi gözyaşları yağmasını ister.]

Dîde-i ebr-i siyâhuñ yaşını diñdürmeyen

Göklere peyveste olan dûd-ı âhumdur benüm

(Üsküplü İshâk Çelebi, G. 173/6)

[Kara bulutlara benzeyen gözün yaşını dindirmeyen, göklere erişen âhlarımın dumanıdır.]

Yeller esdükce yağan yağmur degüldür mutlakâ

Merhamet idüp benüm ahvâlüme ağlar nesîm

(Mesîhî, K. 10/28)

[Rüzgâr estikçe yağan her zaman yağmur değildir. (Bazen de yağmur zannedilen) rüzgârın benim hâlime acıyıp döktüğü gözyaşlarıdır.]

Rüzgârların tabiatla, mevsimlerle, mevsim değişikliklerinin bitkilere etkisiyle ilgili olarak da beyitlerde farklı tasavvurlara rastlanır. Söz gelimi sabâ; bahar mevsiminde eser, baharın habercisidir, çiçekleri açtırır, tabiatın canlanmasını sağlar. Bu anlamda tabiatı dirilticidir. (Batislam, 2005: 113)

Aşağıdaki beyitlerde farklı hayallerle bezeli olsa da rüzgârın yağmurun habercisi olduğu düşüncesi üzerinde durulması yanında ılık esintisiyle çiçeklerin açılmasına, yağmur getirerek tabiatın canlanmasına ve bulutların hareketine olan tesirine de değinildiği görülmektedir.

Mürde iken eyler ihyâ gör zemîni rûzigâr

Emr-i Hakkıla bulutdan her kaçan bârân akar

(Muhibbî, G. 534/6)

[Yeryüzünü ölü (gibi kupkuru) iken Allah’’n emriyle buluttan her vakit yağmur akıtıp canlandıran rüzgârı gör.]

Gülşen-i kûyında yâruñ ağlayup âh eylesem

Açılur gül gibi sanur bâdıla bârân olur

(Muhibbî, G. 790/5)

[Sevgilinin gül bahçesini andıran semtinde âhlar edip ağlasam (sevgili) rüzgârın yağmur getirdiğini sanıp gül gibi açılır.]

Muhibbî bâd-ı âhuñla yaşuñ bârânını dök kim

Görüp bu hâlüñi dilber ide tâ gül gibi hande

(Muhibbî, G. 3064/5)

[Muhibbî, âh rüzgârınla gözyaşı yağmurlarını akıt ki sevgili, bu hâlini görsün de gül gibi açılsın.]

Merdâneler semendi öñinden kaçar vuhûş

Gûyâ ki bâd öñince bulutlar ider firâr

(Taşlıcalı Yahyâ Bey, K. 10/10)

[Bulutların rüzgârın önünde sürüklenmeleri gibi yabanî hayvanlar, yiğitlerin atının önünden kaçar.]

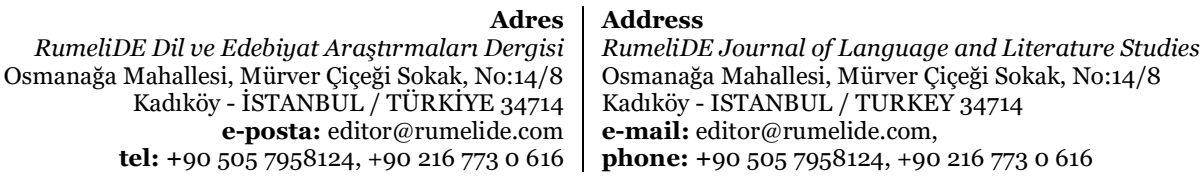




\section{Sel (Seyl)}

Şairin gözyaşı ile vurguladığı en önemli özellik çokluğudur. Büyük bir âş̧ı olarak derin acılar yaşayan klasik Türk edebiyatı şairinin de bir nebze olsun sükûn bulmasını veya aşkının hararetinin azalmasını sağlayabilecek gözyaşları da normal bir gözyaşı olamaz. Âşığın gözyaşları; çok olması, kesintisiz ve coşkun akması sebebiyle genellikle bârân, Ceyhun, deniz, deryâ, girdâb, mevc, tuğyân, ummân gibi benzetilenler kullanılarak ifade edilir. Bu bağlamda gözyaşlarının sele benzetilmesine de sıklıkla rastlanır. Edebî metinlere bakıldığında halk edebiyatı şairleriyle klasik Türk edebiyatı şairlerinin aşağıdaki dipnotta ${ }^{3}$ verilen dörtlükte de görüleceği üzere gözyaşını sele benzetme noktasında benzeştikleri de görülmektedir. (Kahraman, 2000: 253; Selçuk, 2005: 236)

Âşık, sevgilinin ilkbaharı hatırlatan güzelliğini, sevgilinin herhangi bir güzellik unsurunu gördüğü zaman ya da sevgilinin hasretini çektiği için gözyaşlarına hâkim olamaz. Âşı̆̆ın gözyaşları, yağmur gibi yağar; kimi zaman âşığın kendisinin hatta her yerin sular altında kaldığı bir sel olarak tasavvur edilir.

Âhum bulutı yağmurını dökeli gözden

Gark eyledi bu cismümi kaldum sil içinde

(Muhibbî, G. 2852/3)

[Âhımın bulutu gözlerimdem yağmur gibi gözyaşlarımı döktüğünden beri sel içinde kalıp sulara gark oldum.]

Nev-bahâr-ı hüsnüñi görsem yaşum yağmurlayın

Yağuban gark eyleye yir yüzini yaşum seli

(Muhibbî, G. 3518/4)

[Bahara benzeyen güzelliğini görsem, gözyaşlarım yağmur gibi yağarak yeryüzünü sele verir.]

Seyle virdi 'âlemi bârân-ı eşküm âh eger

Hattuñı mahv itmeğe hüsnüñ kitâbından gözüm

(Muîidî, G. 292/5)

[Gözyaşı yağmurum, âlemi sele verdi. Eğer bu yüzden gözüm, güzelliğinin kitabından hattını silerse o zaman mahvolurum.]

Gam-ı hecr ile çeşmümden yağar ol deñlü bârân kim

Belâ seyline varmasun bu âlem korkaram bir gün

(Mu'îdî, G. 366/5)

[Ayrılık acısıyla gözlerimden o kadar yağmur yağar ki âlemin başına bir gün belâ seli gelmesinden korkarım.]

\section{8. Şebnem (Jâle)}

Şebnem, jâle ya da çiy; havadaki su buharının soğuk bir yüzeyde sıvıya dönüşmesiyle oluşan su damlacıklarıdır. Genellikle bahar mevsiminde bazen de yaz mevsiminde sabahın ilk saatlerinde görülür. Güneşin etkisiyle havanın ısınmasıyla da buharlaşarak kaybolur.

Karac'oğlan der ki: Geçdi çağlarım

Meyva vermez oldu gönül bağlarım

Aklıma geldikçe durmaz ağlarım

Gözüm yaşı sel olduğu zamandır. (Cunbur, 1985: 73)

Adres Address

RumeliDE Dil ve Edebiyat Araşttrmaları Dergisi Osmanağa Mahallesi, Mürver Çiçeği Sokak, No:14/8

Kadıköy - İSTANBUL / TÜRKIYE 34714 e-posta: editor@rumelide.com

RumeliDE Journal of Language and Literature Studies

Osmanağa Mahallesi, Mürver Çiçeği Sokak, No:14/8

Kadıköy - ISTANBUL / TURKEY 34714

tel: +90 $5057958124,+902167730616$

e-mail: editor@rumelide.com,

phone: +90 $5057958124,+902167730616$ 
Aşağıdaki beyitte özellikle seher vakitlerinde oluşan şebnemin bitkilerin üzerinde yağmur yağmış gibi bir manzara oluşturduğundan bahsedilmektedir. Beyitte, yüzeyindeki şebnem sebebiyle üzerlerine işık vuran bitkilerin ışıl ışıl göründükleri de dile getirilmektedir.

Ra'd-ı bülbül na'rasıdur kirm-i şeb-tâb aña berk

Eylemişdür gülşeni bârân-1 şeb-nem nûra gark

\section{(Gelibolulu Mustafa Âlî, G. 650/1)}

[Bülbülün gök gürültüsünü (andıran ötüşü) narasıdır, ateş böcekleri şimşekleridir. Şebnem yağmurları, gül bahçesini apaydınlık yapmıştır.]

Bahar bulutundan dökülen yağmurların lâle yaprağı üzerindeki çiy tanelerini andıran damlaları, tabaklara konmuş yuvarlak, taneli yapılarıyla bayram ikramlarından olan çerezlere benzetilmiştir.

Ebr-i bahâr jâleden etbâk-ı lâleye

Toldurdı nukl-i tâze ki ola gıdâ-yı ‘îd

(Hayretî, K. 13/11)

[Bahar bulutu, bayramda yensin diye lâle tabaklarına çiy tanelerinden taze çerez doldurdu.]

Şebnem, aşağıdaki beyitte önce yüze serpilen suya; sonra bu fikirden vazgeçilerek gül bahçesinin la'l renkli tabaklar içine koyup sevgilinin yürüdüğü yollara saçmak için hazırladığı mücevherlere benzetilmiştir. Düğünlerde gelin ve damadın başına veya törenlerde sultanın ayağına para ve değerli şeyler saçmak, eski geleneklerimizden biridir. Hayretî’nin kırmızı renkli çiçekleri la'l renkli tabaklara, bu çiçeklerin üzerindeki çiy tanelerini de gümüş paralara, inciye ve değerli taşlara benzettiği görülmektedir. (Sefercioğlu, 1999: 74)

Pâyına yâ zahm urupdur hâr olupdur bî-mecâl

Şebnem ile su seper yüzine ebr-i dür-feşân

Su degül la'lîn tabaklar içre gevherler durur

Pây-1 yâra nesr içün izhâr idüpdür gülsitân

(Hayretî, G. 15/9-10)

[Diken ayağını yaralamış, sevgili güçsüz kalmıştır; bu yüzden inciler saçan bulut, yüzüne ya çiy taneleri ile su serpmektedir/(ya da) bunlar aslında su değil, gül bahçesinin sevgilinin ayakları altına saçmak için meydana çıkardığı la'l tabaklar içindeki mücevherlerdir.]

\section{Toprak}

Betonarme yapıların olmadığı, evlerin bahçeli olarak kerpiçten yapıldığı ve insanların bağlık bahçelik mekânlarda yaşadıkları eski dönemlerde yağmur yağdığında etrafa misk gibi toprak kokularının bugünkünden fazla yayıldığını söylemek herhalde yanlış olmaz. Nitekim aşağıdaki beyitte sonbahar yağmurlarıyla etrafa güzel kokuların yayıldığından bahsedilmektedir. Beyitte geçen gâliye; misk ve amberden yapılan siyah renkli, güzel kokusu olan bir macundur. Boya olarak kaşa ve saçlara da sürülür.

Başladı yağdı hazân mevsiminüñ bârânı

Toprağı gâliye müşk itmek içün eyledi hal

(Gelibolulu Mustafa Âlî, K. 86/2)

[Toprağa kıvam verip misk kokan macun hâline getirmek için sonbahar yağmurları yağmaya başladı.]

\begin{tabular}{|c|c|}
\hline & \\
\hline RumeliDE Dil ve Edebiyat Araştırmaları De & E Journal of Language and Literature Studie \\
\hline smana ğa Maha & Mahallesi, Mürver Çiçeği Sokak, No:14/8 \\
\hline Kadıköy - & ISTANBUL / TURKEY 34714 \\
\hline tel: +9050 & $\begin{array}{l}\text { e-mail: editor@rumelide.com, } \\
\text { phone: +90 505 7958124, +90 } 216773 \text { o } 616\end{array}$ \\
\hline
\end{tabular}


Aşağıdaki beyitte de âşığın yağmur misali akan gözyaşıyla ıslanan sevgilinin ayağını bastığı toprağın, misk gibi güzel koktuğu dile getirilmektedir.

Ayağı toprağın bârân-ı eşküm idicek nem-gîn

Didi şunı sere ko yüri ser-tâcuñdur â miskîn

(Zâtî, G. 1173/1)

[Gözyaşı yağmurlarım, ayak bastığı toprakları nemlendirince (sevgili bana) ey miskîn, bu toprağı başına koy öyle gez; bu toprak senin başının tacıdır, dedi.]

\section{Tufan}

Sözlüklerde şiddetli yağmur ve bu yağmur neticesinde her yeri kuşatan, taşkınlara sebep olan sel gibi anlamlara gelen tufan, Hz. Nuh devrinde meydana gelen, iman etmeyenlerin şiddetli yağmurlar neticesinde boğuldukları hadisedir. (Şemseddin Sâmî, 2013: 901; İbrahim Cûdî, 2006: 581; Pala, 2015: 460) Kur'ân-ı Kerîm'de de bahsedilen (bkz. Hûd, 11/25-48) bu olayda gökten yağan yağmur, yerden fışkıran su ile birleşmiş, her yer sular altında kalmış ve yalnızca iman edip Hz. Nuh'un yaptığı gemiye binenler kurtulabilmişlerdir.

Bütün dünyayı sular altında bırakan şiddetli yağmur olan tufanın klasik şiir metinlerinde sıklıkla âşığın gözyaşlarıyla ilişkilendirilerek kullanıldığı görülmektedir. Tufan, âşığın yaşadığı aşk derdi sebebiyle döktüğü gözyaşlarının çokluğunu anlatmak için kendisine benzetilen unsur olarak kullanılan bir tabiat olayıdır.

Tûfân-ı eşk-i çeşmüm teskîn iderseñ ey dost

Mânend-i Nûh ‘ömrüñ kllsun Hudâ ziyâde

$$
\text { (Zâtî, G. 1254/6) }
$$

[Ey sevgili, gözyaşı tufânımı dindirirsen Allah, senin ömrünü Nuh’un ömrü gibi uzun etsin.]

Yakam rûy-ı zemîni nâr-ı fürkat böyle kalursa

Virem gark-âba tûfân yaşum ile sûy-ı ummânı

(Rahîmî, G. 333/6)

[Ayrılık ateşi böyle devam ederse yeryüzünü yakayım. Tufan gibi akıttığım gözyaşlarımla okyanusları sular altında bırakayım.]

Beni gark itse tûfân-ı sirişke biñ yaşar dil-ber

Hakîkatde baña ol rûh-ı sânî Nûh-ı sânîuür

(Mostarlı Ziyâî, G. 81/2)

[Beni gözyaşı tufanına boğan sevgili bin yaşasın. O, gerçekte benim için ikinci bir ruh, ikinci bir Nuh gibidir.]

Bâd-ı âhum dökdi şol deñlü yaşum yağmurını

Garka virdi 'âlemi kim dir aña tûfân degül

(Muhibbî, G. 2008/2)

[Âhımın rüzgârı, gözyaşı yağmurlarımı o kadar yağdırdı ki yeryüzü, sular altında kaldı. Kim bu hâle Tufan değil, diyebilir ki?]

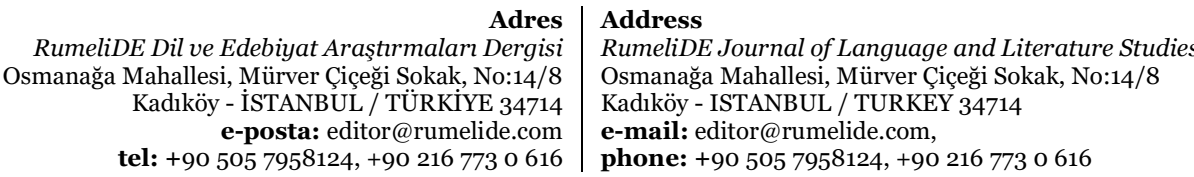

tel: $+905057958124,+902167730616$ 


\section{Yağmur damlası (Katre)}

Şiddetli yağmur, sert esen rüzgâr ile birleşince binalara, canlılara ve tabiata zarar verir. Evlerin çatıları uçar, ağaçların dalları kırılır, ekinler zarar görür, çiçekler, bağlık bahçelik yerler tarumar olur. Yağmur şiddetli yağdığında yağmur damlaları tahrip edici bir etki oluşturur. Bu durum, Nuh Tufanındaki yağmurun tahrip edici etkisini akla getirir.

Garka virdüñ Nûh Tûfânı gibi ezhârı hep

Katresin zehr eyleyen bârâna döndüñ ey felek

(Gelibolulu Mustafa Âlî, K. 738/7)

[Nuh Tufanı gibi bütün çiçekleri sular altında bıraktın. Ey felek, (bu hâlinle) damlasını zehreyleyen yağmura döndün.]

Lâlenüñ kanıla toldurdı sifâlin uralı

Bâga yer yer katre-i bârân ile neşter nesîm

(Mesîhî, K. 10/6)

[Rüzgâr, bağda yer yer yağmur damlalarıyla neşter vurup kadehini lâlenin kanıyla doldurdu.]

Kalbe peykânın irişse ey şeh-i hûbân batar

Yağsa lâbüd hâke yir yir katre-i bârân batar

(Sehâbî, G. 82/1)

[Ey güzeller şâhı, ok temrenin kalbe erişince nasıl tesir ederse toprağa yer yer düşen yağmur damlaları da mutlaka toprağa öyle tesir eder.]

Yerde biriken yağmur suları üzerine düşen yağmur damlaları, düştükleri yerde halkalar oluşturur. Aşağıdaki beyitte su yüzeyinde oluşan bu dairesel şekillerin, ayın çevresini saran hâleye, yağmur damlalarının suya değdiği yerde oluşan su kabarcıklarının ise aya benzetildiği görülmektedir.

Gör âbı ki her dâyire-i nokta-i bârân

Bir hâledür içinde habâbı meh-i tâbân

(Zâtî, G. 1154/1)

[Yağmur damlacıklarının her dairesinin bir hâle, dairesel halkalar içindeki su kabarcıklarının da dolunay olduğu suyu gör.]

Su olan yağmur damlası, esasında yumuşak bir madde olmasına rağmen uzun süre aynı noktaya düşen su damlaları; toprağı, taşı hatta kayaları bile oyacak tesire sahip olur. Mağara tavanlarından aynı noktaya düşen su damlalarının zeminde oluşturduğu oyuklar, bunun en güzel örnekleridir. Sosyal hayatta bunu gözlemleyen divan şairleri, esasında su damlası olan kendi gözyaşlarının da merhametsizlik sebebiyle taşa benzettikleri sevgilinin kalbinde böyle bir tesir oluşturmasını beklerler. Yani suyun taş üzerinde yaptığı tesiri, kendi gözyaşlarının da sevgilinin kalbinde yapmasını umarlar. Bekledikleri tesir, sevgilinin taş kalbinin zamanla sertliğini kaybedip yumuşaması, âşı̆̆ına merhamet edip aşkına karşıllı vermesidir.

Turma ağla iy gözüm ola ki dilber rahm ide

Senge çün bârân ider geçse zamân te'sîrler

(Muhibbî, G. 1045/4)

[Ey gözlerim durma ağla; belki sevgili merhamete gelir. Zira yağmur, taşı zamanla aşındırır.]

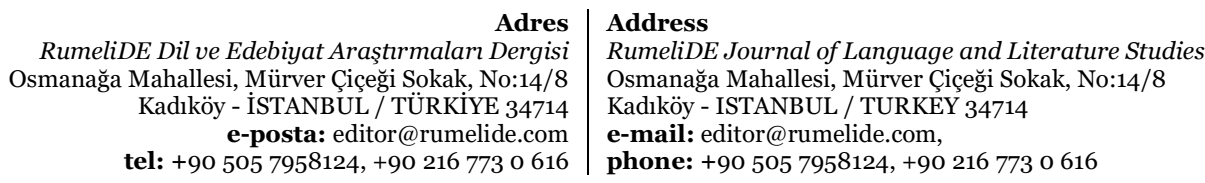


Suyun taşa bile işleyen tesir gücü olmasına rağmen, âşılların gözyaşlarının sevgilinin taş kalbine işlemesi arzu edildiği hâlde bu tesirin gerçekleşmediği hususu, beyitlerde sıklıkla dile getirilen şikâyetlerdendir. Şairler, gözyaşlarının sevgilinin kalbine etki etmemesini, genellikle sevgilinin kalbinin mermer gibi sert olmasına bağlarlar.

Şol kadar bârân-ı eşk âhum sehâbından yağar

Kalbine yâruñ eser itmez 'aceb mermer midür

(Muhibbî, G. 1049/4)

[Âhımın bulutundan o kadar yağmur yağmasına rağmen sevgilinin kalbine tesir etmez. Acaba sevgilinin kalbi mermer midir?]

Âşıklar, sevgilinin kendilerine karşı merhametsiz olmasını sevgilinin kalbinin mermerden olmasına bağlamaları dışında, sevgilinin yapısının yani tüm bedeninin mermerden olması sebebine de bağlarlar. Burada mermerden yapılmış heykellerden de ilhâm alındığı ve mermerin sert bir taş olması yanında beyazlığı ile de sevgilinin teni arasında renge dayalı ayrıca bir ilgi kurulduğu da düşünülebilir.

Hîç noksân gelmedi bârân-1 eşkümden saña

Yoksa mermerden midür ey 'aşk bünyâduñ senüñ

(Rahîmî, G. 162/4)

[Ey sevgili, gözyaşı yağmurlarım sana hiç tesir etmedi. Acaba senin vücudun mermerden mi yapılmıştır?]

Âşığın gözyaşlarının sevgilinin kalbine tesir edip onda bir merhamet duygusu oluşturmamasını şairlerin sevgilinin veya kalbinin sert kaya ya da çelikten yapılmış olmasına da bağladıkları olur.

Eşk-i göñlinden cefâ harfin Celîlî yumadı

İtmedi te'sîr-i bârân nakş-1 seng-i hâreye

$$
\text { (Celîlî, G. 372/7) }
$$

[Sert taşa yağmurun tesir etmediği misali, Celîlı̂nin gözyaşları da gönlünden cefanın izlerini silmedi.]

Dîde-i giryâna rahm itmez Sehâbî kalb-i yâr

Seng-i hârâdur igen kılmaz eser bârân aña

(Sehâbî, G. 24/5)

[Ey Sehâbî, ağlayan gözlerime sevgilinin kalbi merhamet etmez. (Sevgilinin kalbi) sert taştır; yağmur bu sebeple ona fazla tesir etmez. ]

Niçe ylldur eylemez bârân-1 dil te'sîr aña

Şöyle beñzer iy dil-i cânâne sen pûlâdsın

(Muhibbî, G. 2553/3)

[Ey sevgilinin gönlü, sen çeliğe benziyorsun; çünkü gönül yağmurları yllardır gönlüne etki etmedi.]

Umaram yir ide bu bârân-ı eşküm göñline

Gerçi göñli dilberüñ dirler ki seng-i hâredür

(Muhibbî, G. 994/2)

[Her ne kadar sevgilinin gönlü sert taştır, derlerse de umarım bu gözyaşı yağmurlarım gönlüne iz bırakır. ]

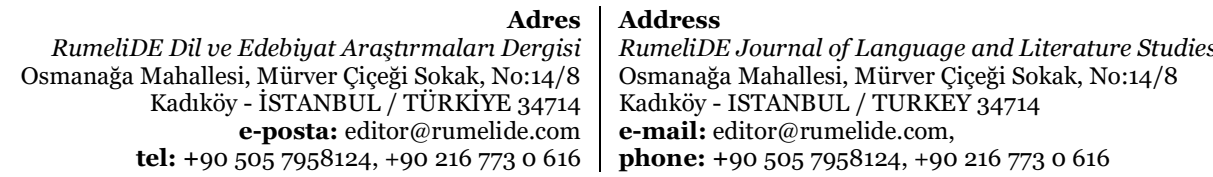

tel: $+905057958124,+902167730616$

e-mail: editor@rumelide.com

phone: +90 $5057958124,+902167730616$ 


\section{Yağmur izi (Rişte-i bârân)}

Yağmur yağarken bulutlardan aşağıya doğru inen çizgiler şeklinde görünen yağmurun gökyüzündeki izleri, aşağıdaki beyitlerde telli müzik aletleri olan erganun ve kanunun tellerine benzetilmiştir. İlk beyitte geçen revân kelimesi, hem gökyüzünden süzülerek akıp giden yağmuru hem de bir müzik terimini kasteder şekilde tevriyeli kullanılmıştır.

Çerh erganûnı tellerini düzdi Zâl-i dehr

Uydı revân usûline bârân akındısı

\section{(Gelibolulu Mustafa Âlî, G. 145/3)}

[Yağmurun gökyüzünden süzülerek akma kaidesine uyarak ihtiyar felek, gökyüzü erganununun tellerini düzenledi.]

Üstâd-ı havâ bağladı kânûn ile bir nakş

Bârânuñ olup rişteleri târ-ı çemenzâr

(Nevî̀, K. 19/6)

[Yağmurun izi çimenin telleri oldu ve havanın üstâdı, kânûn ile bir nakış bağladı.]

Aşağıdaki beyitte gökyüzünde buluttan akan yağmur damlalarının birbiri ardına sicim gibi yağdığında gökyüzünde bıraktığı çizgiler, bu sefer gümüş tele benzetilmiştir. Beyitte sonbahar bulutu, haddeden gümüş tel çekerek sırma yapan kişi olan sîmkeşe; yeryüzü ve gökyüzünün de iki çarka benzetildiği görülmektedir. Beyitte rişte, gümüş tel, sîmkeş, harîf, çarh sözcükleri ile eritilen madenlerden tel yapmak üzere kullanılan hadde aletinin mazmun olarak kullanımı dikkati çekmektedir.

Rişte-i bârân gümiş tel sîmkeş ebr-i harîf

İki çarha döndiler gûyâ zemîn ü âsmân

(Bâkî, K. 22/2)

[Yağmurun izleri, gümüş tel; zanaatkâr bulut, simkeştir. Yeryüzü ve gökyüzü de sanki iki çarka benzemektedir.]

\section{Yıldırım (Şimşek, Berk)}

Yıldırım, bulutta biriken aşırı elektrik yükü neticesinde oluşan gözle görülür, yüksek ışıklı elektrik salınımıdır. Ülkemizde genellikle bahar ve yaz aylarında görülür. Klasik Türk şiirinde âşı̆̆ın içindeki özlemle dertlenip âhlar ettiğinde bu âhların gökyüzüne yükseldiğinden; hatta yıldızlar, ay ve güneşi tutuşturduğundan bahsedilir. Nitekim aşağıdaki beyitte âşığın dertlenip ağladığı zamanlarda âhlar ettiği belirtilerek yağmurun da çok yağdığı zamanlarda yıldırım oluşması durumu arasında ilişki kurulduğu görülmektedir.

\section{Ağlamayınca göñülden kopmaz âh-ı sûznâk}

Olmasa bârân iñende berk-i rahşân oynamaz

$$
\text { (Hayretî, G.136/4) }
$$

[Yağmur şiddetli yağmadığında parlak şimşekler olmadığı gibi, gönülden ağlamayınca da yakıcı âhlar edilmez.]

Geceleyin hastalıklar daha şiddetlenir, derdi olan kişiler de iş güç telaşından ve etraflarındaki insanlardan uzaklaşıp geceleri kendi başlarına kaldıkları için yaşanan acı olaylar zihne daha çok hücum eder. Böylelikle elemler gece vakti insanı daha çok tesiri altına alır. Bu gibi sebeplerle gece; şiirlerde

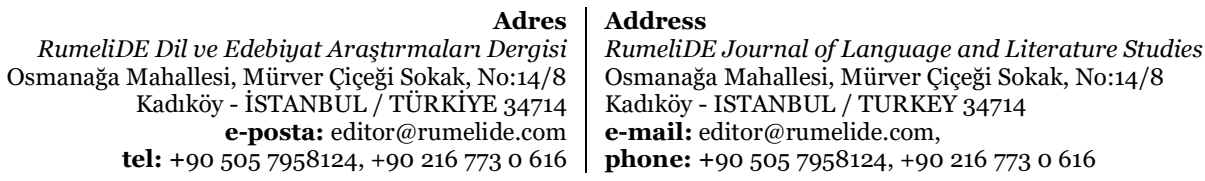


genellikle dert, ıstırap, âhlarla anılır. Aşağıdaki beyitte Zâtî, yağmurlu gecelerde ara ara da olsa karanlığı aydınlatan yıldırımlar olduğunu; oysa kendisinin gecelerden daha karanlık olan gündüzlerini aydınlatan hiçbir şey olmadığını, bu sebeple gündüzlerinin gecelerinden daha ıstıraplı geçtiğini dile getirir. Beyitte yağmurlu havalarda görülen yıldırımların etrafı aydınlatııı özelliğinin dile getirildiği görülmektedir.

Rûşen eyler bârî geh geh anı berk-ı tâb-nâk

Bir yağalu gice yeg biñ gündüzümden dôstlar

(Zâtî, G. 264/3)

[Ey dostlar! Yağmurlu bir gece, hiç olmazsa etrafı ara ara aydınlatan şimşekler olduğundan benim bin gündüzümden daha iyidir.]

Mesîhî̀ye göre "Bağda görünen, gerçekte lâle ve gelincik çiçeği değildir. Şimşek, yağmur neşteriyle bağdan kan almıştır.” denen aşağıdaki bendin ilk iki mısraında firtına, şimşek ve yağmurlu havaların bağlık bahçelik yerlerde meydana getirdiği tahribat dile getirilmektedir.

Bûstânda görinen lâle degül nu'mân ile

Bâgdan kan aldı şimşek neşter-i bârân ile

'Ârif iseñ hoş geçürgil bu demi yârân ile

'Ayş u nûş it kim geçer kalmaz bu eyyâm-ı bahâr

(Mesîhî, Mur. 2/4)

Böylesi bir bahar havasında dalları kırılan, yaprakları etrafa savrulan gelincik ve lâle çiçeklerinin kırmızı yapraklarının kan ile irtibatlandırıldığı görülmektedir. Bentte yer alan kan almak, neşter, eyyâm-ı bahâr sözcüklerinin arka planında hacamat mazmunu olduğu4, şimşeğin ise hacamatçı şeklinde hayal edildiği de görülmektedir.

\section{B. Yağmurla benzetme veya mecaz ilgisi yoluyla ilişkilendirilen unsurlar}

\section{Gözyaşı}

Âşı̆̆ın gözyaşlarının yağmura benzetilmesi; Nev'i, Za î̂fî ve Sehâbî’nin aşağıdaki beyitlerinde olduğu üzere, yağmurdan bahsedilen beyitlerde çok sık karşlaş̧lan bir husustur.

Egilmez bâr-ı âhumdan diyü ol kâmeti servüm

Döküp bârân-ı eşkin şefkatinden rûzgâr ağlar

(Nevî̀, G. 68/5)

[O servi boylu sevgilim, âhımın manevi ağırlığıyla insafa gelmedi diye rüzgâr, bana acıdığından gözyaşı yağmurları dökerek ağlar.]

4 Geleneksel tıp; insan vücudunda safra, sevda, dem (kan) ve balgamdan ibaret ahlât-ı erba'a denen dört sıvının bulunduğu esasına dayanır. Hastalık ve sağlık bu sıvların dengelerindeki değişimle ilişkilendirilir; bu dengenin bozulması, hastalık sebebi olarak değerlendirilirdi. Türkçede kan aldırma anlamına gelen hacamat, geleneksel tıpta yapılan, Peygamberimiz tarafından da uygulanan ve tavsiye edilen bir tedavi yöntemidir. Vücuttaki kirli kanın atılması ile baş, diş, kulak, eklem ağrıları gibi vücudun değişik yerlerindeki ağrıları dindirmek, bu ağrılara sebep olan hastalıkları tedavi etmek için yapılan hacamatın bağışıklık sistemini kuvvetlendirici ve vücuda direnç kazandırıcı bir yönü de vardır. Yakın zamanlara kadar hipertansiyon, kalp yetmezliği, sarılık, zehirlenme gibi hastalıklarda ve yaralanmalarda yaraların enfekte olmasını önlemek için hastalardan kan alınırdı. (Akdağ, 2014: 170-172; Kemikli, 2007: 24; Yeniterzi, 1990: 98)

Adres | Address

RumeliDE Dil ve Edebiyat Araştırmaları Dergisi Osmanağa Mahallesi, Mürver Ciçeği Sokak, No:14/8

Kadıköy - İSTANBUL / TÜRKIYE 34714 e-posta: editor@rumelide.com

RumeliDE Journal of Language and Literature Studies

Osmanağa Mahallesi, Mürver Çiçeği Sokak, No:14/8

Kadıköy - ISTANBUL / TURKEY 34714

tel: $+905057958124,+902167730616$

e-mail: editor@rumelide.com,

phone: +90 5057958124 , +90 2167730616 
Katre katre dökülen eşkile hicrüñde bu âh

Biri bârân-ı cihân oldı biri ebr-i siyâh

(Za'îfî, G. 275/1)

[Senin ayrılı̆̆ın yüzünden damla damla dökülen gözyaşı ve çekilen bu âhtan biri dünyayı sele veren yağmur, diğeri kara bulut oldu.]

Bârân-ı eşki yolına durmaz nisâr ider

Çeşmüm Sehâbî giryede gûyâ sehâbdur

(Sehâbî, G. 94/6)

[Sehâbî, gözüm sanki bir bulutmuş gibi sevgilinin uğruna gözyaşı yağmurlarını durmadan akıtır.]

Nevî̀nnin “Âşı̆̆ın bir karşılık almamasına rağmen bu cihan tarlasını çokça akıttığı gözyaşları yağmuru ile sulaması ne gariptir.” dediği aşağıdaki beyitte yağmurlar tarlada mahsul meydana getirirken âşı̆̆ın yağmur gibi akıttı̆̆ı gözyaşları neticesinde elde ettiği bir şeyin olmadığı vurgulanmaktadır.

'Âşıkuñ kesret-i bârân-ı sirişki ne 'aceb

Bu cihân mezra'asın eyler ise bî-hâsıl

(Nevî̀, G. 282/2)

Gelibolulu Mustafa Âlî̀nin "Benim utanmam, ümidimin çorak tarlasını çok uzun zamandan beri boş yere yağmur misali gözyaşlarımı akıtarak sulamam sebebiyledir.” şeklinde düzyazıya dil içi çevirisi yapılabilecek aşağıdaki beyitte yine âşığın gözyaşlarının boş yere aktığı, sevgili cephesinde tesir gücüne sahip olmadı $\breve{g}$ dile getirilmektedir.

'Ârum andandur zemîn-i şûre-i ümmîdüme

Niçe bir yok yirlere gözyaşı bârân eyleyem

(Gelibolulu Mustafa Âlî, K. 13/51)

Âşık, sevgilinin yanağına duyduğu hasretle elemlere gark olur. İçine düştüğü ve çözüm bulamadığı bu derdin ıstırabı, âşığın vücudunda yaralar oluşmasına yol açmıştır. Sinede uç veren, kimi zaman da kanayan bu yaralar, klasik şiir geleneğinde genellikle kırmızı renk ile özdeşleştirilen güle benzetilmiştir. (Bayram, 2007: 211) Âşı̆̆ın sinesindeki bu güllerin sulanması da âşığın sevgilinin elemiyle yanaklarından akıp sinesine dolan gözyaşları ile olmaktadır.

Dâg-ı gam-ı ruhuñla bârân-ı eşk-i çeşmüm

Bitürdi tâze güller hâk-i tenümde yir yir

(Hayretî, G. 119/2)

[Gözyaşı yağmurum; senin yanağının gamı yüzünden oluşan yaralarla, tenimin toprağında yer yer taze güller yetiştirdi.]

Gelibolulu Mustafa Âlı̂’nin “Cenk dağına gök gürültüsünü andıran tüfek seslerinin yankılanması erişse düşmanın gözünden yağmur gibi gözyaşlarını akıtır.” dediği aşağıdaki beyitte şiddetli yağmurlarda büyük bir patlamayla oluşan gök gürültüsünün insanda uyandırdığı korku duygusu, şairin söz konusu beyti oluşturmasındaki temel hareket noktası olmalıdır.

Akıdur eşkini bârân gibi 'ayn-ı a'dâ

Ra'd-veş düşse vegâ kûhına pejvâk-ı tüfeng

(Gelibolulu Mustafa Âlî, K. 24/14)

\begin{tabular}{r|l} 
Adres & Address \\
RumeliDE Dil ve Edebiyat Araştırmaları Dergisi & RumeliDE Journal of Language and Literature Studies \\
Osmanağa Mahallesi, Mürver Çiçeği Sokak, No:14/8 & Osmanağa Mahallesi, Mürver Çiçeği Sokak, No:14/8 \\
Kadıköy - İSTANBUL / TÜRKİY 34714 & Kadıöy - ISTANBUL / TURKEY 34714 \\
e-posta: editor@rumelide.com & $\begin{array}{l}\text { e-mail: editor@rumelide.com, } \\
\text { phone: +90 505 7958124, +90 } 216773 \text { o } 616\end{array}$ \\
tel: +90 505 7958124, +90 216773 o 616 &
\end{tabular}


Şair, gök gürültüsünün insanlar üzerinde oluşturduğu ürkme, korkma duygusu; hatta küçük çocukları ağlatma durumu ile savaş meydanlarında topluca patlayan tüfek sesleri arasında ilgi kurmakta ve bu seslerin düşmanın yüreğine korku salacak hatta belki onu korkusundan ağlatacak kadar güçlü olduğundan bahsetmektedir.

Burada dikkat çekici diğer bir husus tüfeng sözcüğünün kullanımıdır. Tüfeng, bugün tüfek dediğimiz uzun namlulu, ateşli bir silahtır. 16. yüzyılın başlarında icat edilen tüfeğin, o günlerde nispeten az bilindiği, az kullanıldığı tahminen ileri sürülebilir. (Aybet, 1989: 308)

Sultan Murad Han’n (ö. 1595) övgüsünün yapıldığı bir kasideden alınan aşağıdaki beyitte sultanın döneminde toprağa düşenin sadece yağmur ve yıldırım; gözyaşları şeklinde akan tek şeyin de yağmur olukları olduğu dile getirilmektedir. Bu şekilde sanatlı bir ifade ile söylenmek istenen, Sultan Murad Han devrindeki hakkaniyetli yönetim ile kıymetli olan her şeye değer verildiği, kimsenin değersiz görülmediği; bunun sonucu olarak da haksızlığa uğrayan olmadığı ve mazlumların gözyaşlarının akmadığıdır.

Hâke düşmez kimse devrüñde meger bârân u berk

Gözyaşın dökmez zemânuñda meger kim nâvdân

(Gelibolulu Mustafa Âlî, K. 35/19)

Yağmur, bitkilerin büyüyüp gelişebilmesine nasıl fayda sağlıyorsa insanların manevi gelişiminde de ağlamak; daha doğrusu ağlayabilecek hissiyata, hassas bir kalbe sahip olmak, öyle fayda sağlar. Hislenebilen kalp ve ağlayabilen göze sahip kişi, gönlündeki güzelliği amelle de taçlandırabiliyorsa önünde bazı manevi kapılar açılacaktır. Gözyaşlarının yağmura benzetildiği aşağıdaki beyitlerde ağlayabilmek ile kişinin manevî gelişimi arasında ilişki kurulduğu görülmektedir.

Yağmaz ise sirişk bârânı

Bu ten-i hâksârdan ne biter

(Gelibolulu Mustafa Âlî, G. 240/3)

[Gözyaşı yağmurları yağmazsa, toz toprak içinde kalmış bu vücuttan ne bitebilir ki?]

İlâhî olmasun bir lahza hâlî akmadan yaşum

Dil ü cân mezra'ın ser-sebz ider bârân-ı rahmetdür

(Hayretî, G. 83/4)

[Ey Allah’ım! Gözyaşım, ruh ve gönlü yeşillendiren rahmet yağmuru olduğundan, bir an bile olsa akmaktan boş kalmasın.]

Gözüñ bârân-ı eşki dökdügince

Olur gül gibi bu ‘ömrüñ küşâde

(Muhibbî, G. 4086/3)

[Gözün gözyaşı yağmurlarını döktüğü sürece ömrün, gül gibi açılmış olur.]

\section{2. İnci}

İnanışa göre nisan yağmurlarında denizin yüzeyine ya da sahile çıkan sadef, kabuklarını açar, ortasına düşen yağmur damlasını yutar ve denizin derinliklerine dönermiş. Sadefin yuttuğu yağmur tanesi, bir süre sonra hayvana ıstırap verince sadef, acısını dindirmek için bir salgı salgılarmış. Bu salgılar, zamanla

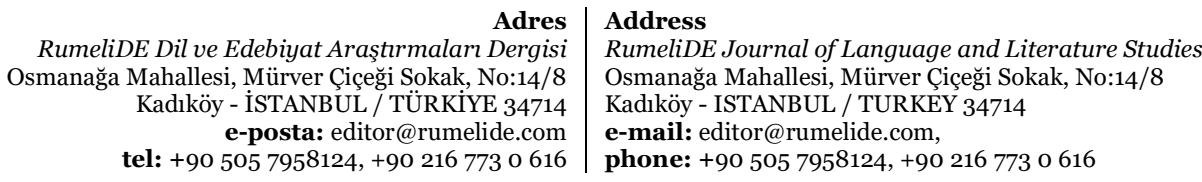


yağmur damlasını saran, üst üste biriken bir katman oluşturup katılaşınca da inci oluşurmuş. (Kırbıyık, 2007: 65)

Aşağıdaki beyitlerde sevgilinin bakışının âşığın gözünde saklanması hâli ve bu hâlin sadef içinde büyüyüp gelişen inciye benzetilmesine dayanan bir hayalin yer aldığı görülmektedir. Tahrip ediciliğini artırmak için okun ucuna eklenen sivri demir kısma peykân veya temren denir. Beyitlerde peykân ile yağmur damlasının irtibatlandırılması, iki varlı̆̆ın da özünde su taşımaları itibariyledir. Peykânın yapıldığı demirin sertliğini artırmak için demire su verilir. Bu yönüyle peykân ile su ilişkilendirilir.

Gözümde beslenüp kıymet bulan peykânuñı gördüm

Sadefde gevher olan katre-i bârâna beñzetdüm

(Fuzûlî, G. 198/5)

[Gözümde beslenip kıymet bulan ok temrenini görünce onu sadef içinde inci olan yağmur damlasına benzettim.]

Göz ki peykânuñ hayâliyle saçar her yan sirişk

Bir sadefdür katre-i bârânı eyler dürr-i nâb

(Fuzûlî, G. 28/6)

[Senin ok temrenini hayal ederek her yana gözyaşı akıtan göz, yağmur damlasını hâlis inci eden bir sadeftir.]

Ma'rifetde ağzumuz la'l-i Bedahşân yağdurur

Nitekim deryâya dürler ebr-i nîsân yağdurur

(Taşlıcalı Yahyâ Bey, Mua. 11-2/3)

[Nisan bulutunun denize inciler yağdırması gibi, ilimde de ağzımız Bedahşân la'li gibi kıymetli ilimleri bol bol anlatır.]

Teşnedür dil bahr-i gamda oklaruñ peykânına

Ağız açmış bir sadefdür katre-i nîsân umar

(Nevî̀, G. 96/4)

[Gönül, nisan yağmuru damlasını umarak sadefin kabuklarını açması gibi, gam denizinde senin oklarının temrenine arzuludur. ]

\section{Ok}

Yağmur ile ok arasındaki benzerlik ilişkisi, beyitlerde sıklıkla karşılaşılan bir durumdur. Bu benzetmede ok ile yağmurun tane tane olması, havada birbiri ardına sıralanması ve savaş ortamında topluca atılan oklar düşünülecek olursa çok sayıda olup bunların yukarıdan aşağıya doğru düşmeleri gibi yönlerle ilgi kurulduğu düşünülebilir. Yağmur tanelerinin oka benzetildiği beyitlerde okun atıldığı yay da genellikle gökkuşağı olarak düşünülür.

Ceng ider 'ş̧kuñ yolında âsmân ile zemîn

Sanki bârân tîrdür kavs-i kuzah ey meh kemân

(Meâlî, G. 177/6)

[Ey ay yüzlü sevgili, senin aşkın uğrunda yeryüzü ve gökyüzü savaştadır. Yağmur sanki oktur, gökkuş̧ă̆ı da yay.]

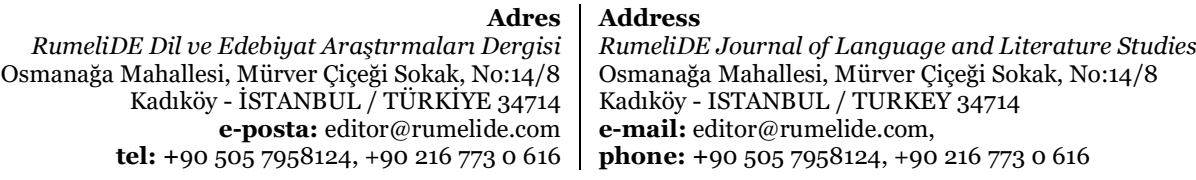

tel: +90 $5057958124,+902167730616$ 
Dem-i a'dâ ile deşt-i cihânı lâle-zâr itdi Sipâh-ı berk-reftâr-ı Tâtâruñ tîr-bârânı

(Bâkî, K. 14/24)

[Tatar'ın şimşek gidişli askerinin ok yağmurlarıyla (dökülen) düşmanların kanı, dünyayı lâle bahçesine çevirdi.]

Berk-i âh u ra'd-ı nâlem tutmasun mı 'âlemi

Yağdurur çarh okların bârân gibi her bâr çarh

(Zâtî, G. 103/7)

[Felek, oklarını daima yağmur gibi yağdırır. Âhımın şimşeği ve feryadımın gök gürültüsü her yere yayılmasin mi?]

Ne gam bârân gibi yağarsa tîr-i ta'n ey 'Âşık

Baña tek sâye-i serv-i hırâmânum penâh olsun

$$
\text { (Âşık Çelebi, G. 69/5) }
$$

[Ey âşık, salınan servimin gölgesi sı̆̆ınağım olsun da ayıplanma oku üzerime yağmur gibi yağarsa da mühim değil.]

Sevgilinin âşı̆̆ı dertten derde salan ve sinesini ok gibi delen bakışları, aynı zamanda âşığın kalbini yaralar. Âşı̆̆ın yaşadığı dert nedeniyle sinesini yumruklaması, sinesinde yaralar oluşmasına neden olur. Bu yaralar, genellikle lâlenin ortasındaki siyahlığa benzetilir. Kan oturan bu yaralardan akan kanların güle benzetildiği ya da âşı̆̆ın sinesinin lâle bahçesi gibi kıpkırmızı göründüğüne de şiirlerde rastlanır.

Bâg-ı cismümde demâdem lâleler bitürmeğe

Tîrüñ ucından şehâ bârân-veş peykân yağar

(Mesîhî, G. 92/2)

[Ey şâh, vücut bahçemde sürekli lâleler yetiştirmek için okun vesilesiyle üzerime yağmur gibi temren yağar.]

Tâzelendürmeg içün yüregümüñ lâlelerin

Yağdurur gamzeleri tîrini bârân-şekil

(Mesîhî, G. 150/2)

[Sevgili, yüreğimin lâlelerine yenilerini eklemek için gamze oklarını üzerime yağmur gibi yağdırır.]

Ben hâke idüp tîrini bârân o kaşı yâ

Sînem bitürür yaralarımdan gül-i hamrâ

(Nevî̀, G. 7/1)

[O yay kaşlı sevgili, ayağı altındaki toprak olan bana oklarını yağmur gibi atınca göğsüm, yaralarımdan kırmızı gül meydana getirir.]

\section{Tükürük}

Güller, hadlerini bilmeyerek sevgilinin hiç sahip olamayacakları yanağının kırmızılığına özenip sevgiliyi taklide yeltenmişlerdir. Bu, nahoş bir durum oluşturmuştur ve güllerin bu yaptığı densizliğe karşı saba, güllerin yüzüne tükürmüştür. Beyitte hüsn-i talil yoluyla yağmurlu havalarda, rüzgârda etrafa savrulan, güller üzerinde biriken yağmurun tükürük olarak değerlendirildiği görülmektedir. 
Bî-hayâlık eyleyüp öykündügiçün haddüñe
Güllerüñ bârân ile yüzine tükürdi sabâ

(Meâlî, G. 17/2)

[Sabah yeli, hadlerini bilmeyerek sevgilinin yanağını taklide çalıştığı için güllerin yüzüne yağmur ile tükürdü.]

Yine bir hüsn-i talilin dikkat çektiği aşağıdaki beyitte sevgiliyi taklit etme cüretinde bulunmanın cezalandırılması çerçevesinde düşünülebilecek bir durumdan söz edilebilir. Beyitte bu sefer, sevgilinin yanağı ve gözü ile kendilerini kıyas etme hadsizliğinden dolayı gülün ve nergisin yüzünde rüzgâr ve yağmurun yara bere açtığı dile getirilmektedir. Rüzgârın şiddetiyle birleşen yağmurun, çiçekleri koparıp savurması, dallarını kırması; şair muhayyilesinde sevgiliye benzemeye çalışan çiçeklere rüzgârla yağmurun müştereken verdikleri bir ceza olarak değerlendirilmiştir.

Hadd ü çeşmüñe gül ile nergis öykündügiçün

Bâd ü bârân anlaruñ yüzin gözin evgâr ider

(Meâlî, G. 228/3)

[Gül ve nergis senin yanağını ve gözünü taklide çalıştığı için rüzgâr ve yağmur, onların yüzünü gözünü yaralar.]

Memduhun inciler dağıtan cömert elini taklit etmeye çalıştı̆̆ için bulutların denizin yüzüne tükürdüğünün ifade edildiği aşağıdaki beyitte de hüsn-i talil yoluyla bulutlardan dökülen yağmurların tükürük olarak tasavvur edildiği görülmektedir.

Bahrüñ tükürür yüzine her lahza bulutlar

Öykündügiçün keff-i güher-pâşuña deryâ

(Mesîhî, K. 16/22)

[Deniz; senin inciler dağıtan elini taklide çalıştığı için bulutlar, her an denizin yüzüne tükürür.]

\section{Yağmurla ilgili âdet, inanış ya da tecrübeye dayalı bilgiler}

\section{Ayın etrafi hâlelenince yağmur çok yağar}

Âşık Çelebi’nin "Sevgilinin yüzünde ayva tüyleri çıktı̆̆ından beri gözyaşlarım arttı, ayın etrafında hâleler olduğunda yağmur fazla yağar." dediği aşağıdaki beytinde sevgilinin yüzü aya, ayva tüyleri ise ayın etrafındaki hâleye benzetilmiştir. Beyitte vurgulanacak diğer bir husus ayın etrafında hâle olduğunda yağmurun fazla yağacă̆ı inanışının olmasıdır. Bu inanış, Zâtî’den alınmış olan ikinci örnekte de net biçimde görülmektedir.

Hattun irişeliden olupdur füzûn yaşum

Ağıllanıcak ay ziyâde olur matar

$$
\text { (Âşık Çelebi, G. 84/4) }
$$

Yâri 'uryân havzda görsem gözüm giryân olur

Hâle kim mâhı ihâta eyleye bârân olur

$$
\text { (Zâtî, G. 161/1) }
$$

[Hâle, ayın etrafını sarınca yağmur yağdığı için sevgiliyi havuzda çıplak görsem gözlerimden yaşlar akar.]

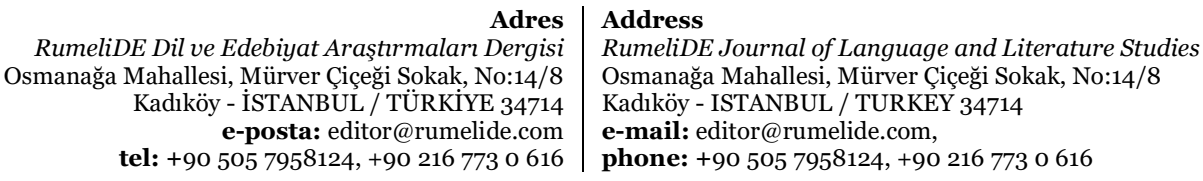

RumeliDE Journal of Language and Literature Studies

Osmanağa Mahallesi, Mürver Çiçeği Sokak, No:14/8

Kadıköy - ISTANBUL / TURKEY 34714

e-mail: editor@rumelide.com,

phone: +90 505 7958124, +90 2167730616 
Yukarıdaki beyitte de ayın etrafında hâle olduğunda yağmurun çok yağacağına olan inanışın Zâtî tarafından farklı bir hayale dayandırıldığı görülmektedir. Buna göre havuza giren sevgili ay; sevgiliyi çevreleyen sular ayın hâlesi; bu manzarayı gören âşığın gözyaşları da yağmur olarak tasavvur edilmiştir. Şair, bu şekilde ayın etrafında hâle olunca yağmur yağacağı halk inanışının temel unsurları olan ay-hâleyağmur bağlantısını sırasıyla sevgilinin bedenine, havuzun suyuna ve âşığın gözyaşlarına karşılık gelecek şekilde tasarlamıştır.

Aşağıdaki beyitte yine ayın etrafında parlak halka şeklindeki ışık olan hâleler olduğunda yağmur yağacağına dair inanış vurgulanmaktadır.

Hâle-i hattuñı gördükde Muhibbî ağlasa

Tañ midur bârân olur diyü müneccimler yazar

(Muhibbî, G. 580/5)

[Muhibbî, senin yüzünü hâle gibi saran ayva tüylerini gördüğünde ağlasa buna şaşılır mı? Zira müneccimler, hâle olunca yağmur yağar, diye bildirmektedir.]

\section{Bulutlar alaçlık olduğunda yağmur durur}

Gökyüzünü kara bulutlar sardığında genellikle kısa süre içerisinde yağmur yağmaya başlar. Aşağıdaki beyitte gökyüzünde kümelenmiş bu kara bulutlar, dağılıp daha açık gri renge döndüklerinde ise yani alaçlık olduğunda yağmurun biteceği inanışına yer verildiği görülmektedir. Şair, ayrıca gökyüzünün sonsuza kadar kararıp kalmadığı; dolayısıyla yağmurun nihayeti olduğu gerçeğinden hareketle kendi gönlüne onu kara bulutlar gibi saran gamdan bir gün kurtulacă̆ını söyleyerek metanetli olmaya çalışır.

Açılur gaym-ı gamun ağlama bir gün ey dil

Çün alaçlık oluban buldı nihâyet bârân

(Hayretî, G. 356/3)

[Ey gönül, gam bulutun bir gün elbet dağılır, ağlama; çünkü kara bulutlar açık renge döndüğünde yağmur durur.]

\section{3. İnci yağmur tanesinden oluşur}

Yukarıda da bahsedildiği gibi inanışa göre nisan yağmurlarında denizin yüzeyine ya da sahile çıan sadef, kabuklarını açar, ortasına düşen yağmur damlasını yutar ve denizin derinliklerine dönermiş. Sadefin yuttuğu yağmur tanesi bir süre sonra hayvana sstırap verince sadef, acısını dindirmek için yağmur damlasını çevreleyen bir salgı salgılarmış. Bu salgılar üst üste katman oluşturup katılaşınca da inci oluşurmuş. (Kırbıyık, 2007: 65)

Aşağıdaki beyitte sevgilinin bakışının âş̧ı̆ın sadefe benzetilen gözünde saklanması hâli ve bu hâlin sadef içerisinde büyüyüp gelişen inciye benzetilmesine dayanan bir hayalin yer aldığı görülmektedir.

Gözümde beslenüp kıymet bulan peykânuñı gördüm

Sadefde gevher olan katre-i bârâna beñzetdüm

$$
\text { (Fuzûlî, G. 198/5) }
$$

[Gözümde beslenip kıymet bulan ok temrenini görünce onu sadef içinde inci olan yağmur damlasına benzettim.]

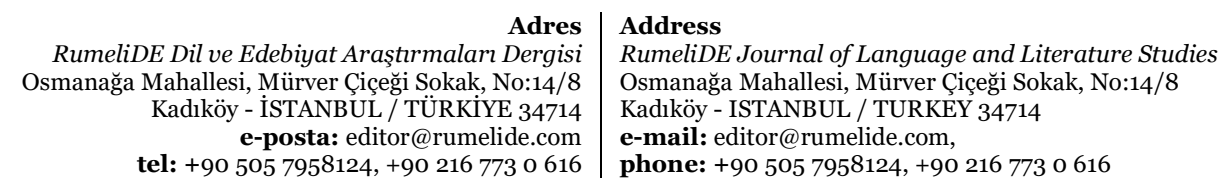

tel: $+905057958124,+902167730616$ 
Hamd olsun Allâha kim dünyâya bârân yağdurur

Lü’lü'-yi lâlâ kılur bârân-ı nîsân yağdurur

(Ǘsküdarlı 'Aşkî, G. 76/1)

[Dünyaya yağmur yağdıran, yağdırdı̆̆ı nisan yağmurunu parlak inci yapan Allah’a şükürler olsun.]

İden bârân-ı nîsândan sadef ağzın tolu lü'lü'

Dehânuñ pür-güher bir hokka-i mercâna beñzetmiş

(Üsküdarlı 'Aşkî, G. 192/4)

[Nisan yağmurunu inci edip sadefin ağzını dolduran (Allah), senin ağzını da içi incilerle dolu mercan bir hokkaya benzetmiş.]

Nisan yağmurlarının sadefin karnında inciye dönüştüğü inanışı gibi yılan zehrinin yllanın nisan yağmurundan yuttuğu damlalar ile oluştuğu inanışı da klasik Türk edebiyatı metinlerinde yer alan hususlardandır. Aşağıdaki beyitte bu inanışa telmih yapıldığı görülmektedir.

Figân ki şâh-ı emel itse kasd neşv ü nemâ

Matar yirine felek zehr-i mâr feyz eyler

\author{
(Âşık Çelebi, K. 14/92)
}

[Eyvahlar olsun ki emel dalı; büyüyüp gelişmeye niyet etse felek, yağmur yerine yılan zehri akıtır.]

\title{
4. Kara bulutlar yağmur getirir
}

Nevî̀nnin “Gökyüzü bulutlandığında insanların bunu görüp yağmuru beklemeleri gibi, sevgili yaya benzer kavisli kaşlarını çattığında âşığın gönlüne sevgilinin göz-kaş ve kirpikleriyle meydana getirdiği gamze okları düşer.” dediği aşağıdaki beyitte gökyüzündeki kara bulutların yağmurun habercisi olduğu inanışına yer verildiği görülmektedir. Beyitte sevgilinin kaşlarını çatışı, gökyüzünü saran kara bulutlara benzetilmiştir.

Yâ kaşuñ çîn olsa kalbe tîr-i müjgânuñ düşer

Gökde kim ebre girih düşse kişi bârân umar

(Nev̂̂, G. 96/2)

Aşağıdaki beyitte yine gökyüzünü kara bulutlar kapladığında kısa bir süre sonra yağmur yağacağı inanışı dile getirilmektedir.

'Aceb mi âh kıldukca gözümüñ yaşı diñmezse

Kaçan ebr-i siyâh olsa hemân ardıncadur bârân

(Muhibbî, G. 2419/4)

[Âhlar ettiğim sürece gözümün yaşının dinmemesine şaşılır mı? Zira ne zaman kara bulutlar görünse hemen ardından yağmur yağar.]

\section{Kara yel tufan getirir}

Kara yel; kuzeybatıdan sert, soğuk esen ve yağmur getiren yerel bir rüzgârdır. Bu rüzgâr ile klasik şiirde, aşk derdi sebebiyle âşı̆ıı ağzından gökyüzüne siyah bir duman şeklinde yükseldiği düşünülen âhları arasında ilgi kurulur. Bu ilgi, daha çok âşığın dertlenip âh etmesinin ardından gözyaşlarının akması hâli gibi, bir yerde kara yel esmesinin ardından yağmur yağacağına olan inanışa dayandırılır.

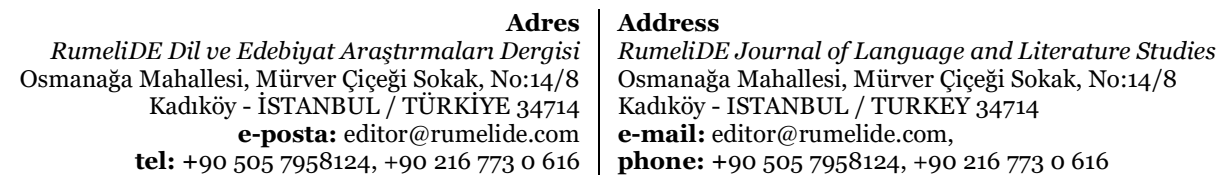


Dûd-ı âhum lahza tûfân yağdurur

Esdügince Karayil dirler ki bârân yağdurur

$$
\text { (Mu'îdî, G. 85/1) }
$$

[Âhımın dumanı bir anda şiddetli yağmur yağdırır. Zira Karayel estiği sürece yağmur yağar derler.]

Aşağıdaki beyitlerde kıble rüzgârının ve gün doğusundan ya da bazılarına göre seher vakti kıble tarafindan esen sabah rüzgârının da yağmur getirdiğinin ifade edildiği görülmektedir.

Turmadı kıble yili esdi bulutlandı hevâ

Sanasın Ka‘be tarîkinde katar oldı cemel

(Gelibolulu Mustafa Âlî, K. 86/3)

[Kıble yeli durmadan esti, hava bulutlandı. (Bulutlar) Ka'be yolundaki develer gibi sira sira dizildiler sanki.]

Mezra'-ı dilde çün ekdüm ben mahabbet tohmını

Ebr-i âhumdan ne tañ yağdursa ger bârân sabâ

$$
\text { (Muhibbî, G. 115/6) }
$$

[Gönül tarlama aşk tohumunu ektiğim için sabah rüzgârı âhımın bulutundan yağmur yağdırsa buna şaşılır mı?]

\section{Kurban bayramında yağmur yağar}

Yağmurla irtibatlı diğer bir halk inanışı, bayram gününde yağmur yağacağıdır. Kimi bölgelerde bugün dahi yaşayan bu inanış, özellikle kurban bayramı için geçerlidir. İnanışa göre kurban bayramında yağmur yağar ve bu zamanda yağan yağmur, kesilen kurbanın Hak katında kabul olduğu düşüncesiyle ilişkilendirilir. Ayrıca kurbanlık olarak kesilen hayvanların kanlarının temizlenmesi için yağdığı düşüncesi de söz konusudur.

Pertev Naili Boratav, eski dönemlerde yağmur yağdırmak için yapılan uygulamalardan birisinin kurban kesmek olduğunu belirtir ve kurban bayramı günü yağmur yağacağına olan halk inanışının kökeninin bu uygulama olabileceğini dile getirir. (Boratav, 1950:V-II/1222-1223)

Aşağıdaki beyitlerde kurban bayramında yağmur yağdığı inanışına doğrudan ya da dolaylı olarak yer verildiği görülmektedir.

'Arz-1 hâl idemedüm yâri görüp ağlamadan

Yılda bir ‘îd olup ol dahı bârân oldı

(Bursalı Rahmî, G. 208/3)

[Sevgiliyi görüp de ağlamadan bir kez bile olsa durumumu ona açamadım. Zira yılda bir kez bayram geldi; o günde de (gözyaşlarım) yağmur (gibi) yağdı.]

Rûz-1 î̀d oldukca yağmur yağdurur sanmañ felek

Ağzı suyın akıdur dil-berler içün her melek

(Gelibolulu Mustafa Âlî, K. 736/1)

[Felek, bayram olduğu her zaman yağmur yağdırır zannetmeyin. Melekler, güzelleri görünce ağızlarının suyu akar.]

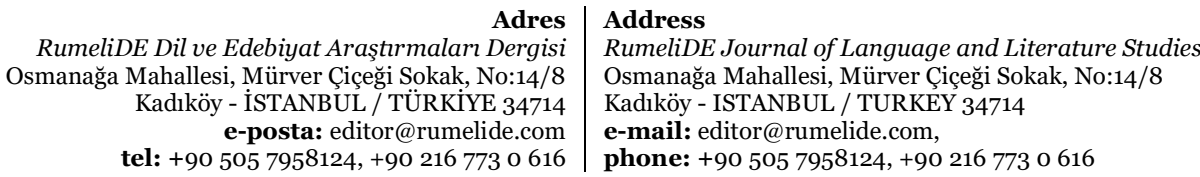

tel: $+905057958124,+902167730616$ 
Feyz-i ihsânun göñül bâgını sîr-âb eyledi

Ser-be-ser bûstân-ı dehri nitekim bârân-ı ‘îd

(Rahîmî, G. 39/8)

[Bayram yağmurunun dünya bostanını baştan başa sulamasına denk, lütfunun bolluğu; gönül bahçesini suya doyurdu.]

Vuslatuñı eşk-i çeşmümdür demâdem men` iden

Kim bozlur kesret-i bârândan hengâm-1 î̀d

(Mesîhî, G. 39/2)

[Sana kavuşmaya daima engel olan gözyaşlarımdır. Zira bayram cemiyetleri, şiddetli yağmur sebebiyle dağılır.]

‘Âleme ebr-i kefüñ bârân-ı ihsân yağdurur

Ağmasun göge sehâb u yağmasun bârân-1 î̀d

(Üsküdarlı 'Aşkî, K. 22/18)

[Elinin bulutu dünyaya lütuf yağmurları yağdırır. (Elin varken boş yere) bulut, gökyüzüne yükselip bayram yağmuru yağdırmasın.]

Aşağıdaki beyitte kurban bayramında etrafa saçılan kanları temizlemek için yağmurun yağması inanışından mülhem olduğu düşünülebilecek farklı bir inanışa yer verilmiştir. Bu inanışa göre, savaş meydanında etrafa bulaşan düşman kanlarının temizlenmesi için savaştan sonra gazâ yağmuru yağar.

Yumağa sümm-i semendüñdeki a‘dâ kanın

Yağar elbetde savaş irtesi bârân-ı gazâ

(Üsküdarlı Aşkî, K. 17/8)

[Atının tırnağındaki düşmanların kanını temizlemek için elbette savaştan sonra gazâ yağmuru yağar.]

\section{Sihir ile yağmur yağdırılır}

Hakkındaki ilk bilgilere Çin kaynaklarında rastlanan ve farklı Türk boylarının lehçesinin fonetik özelliğine göre yat, yada, sata, cay, cada gibi değişik şekillerde isimlendirilen yada taşı inancı çok eski devirlerden beri mevcuttur. Yada taşı, farklı Türk kavimlerinde çok eski devirlerden beri var olan yaygın inanca göre büyük Türk tanrısı tarafından Türklerin atalarına armağan edilmiş ve istenildiği zaman yağmur, kar, dolu yağdırıp fırtına çıkarmak için şamanlar tarafından kullanılan sihirli bir taştır. (İnan, 1986:160)

Divânü Lügâti't-Türk'te yat maddesinde yada taşından bahsedilir. Buradaki açlklamaya göre yat bir nevi kâhinliktir ve belirli taşlarla (yada taşı) yapılır. Bu taş ile rüzgâr estirilip yağmur ve kar yağdırıldığından bahsedilir. Bu uygulamanın Türkler arasında bilinen bir şey olduğu; hatta Kaşgarlı Mahmud, Yağma ülkesinde yaz mevsiminde çıkan bir yangını söndürmek için yada taşı kullanılarak Allah’ı izni ile kar yağdırılıp yangının söndürüldüğüne kendisinin de şahit olduğunu belirtir. (Atalay, 1999: 3)

Yada taşının taşa kan sürme (İnan, 1976: 251), ele alınıp yukarı kaldırma (İnan, 1986: 163), suyun içine atma, havada sallama veya taşı ağızda tutma (Polat, 2007: 278-279) gibi farklı usullerle yağmur yağdırdığına inanılır.

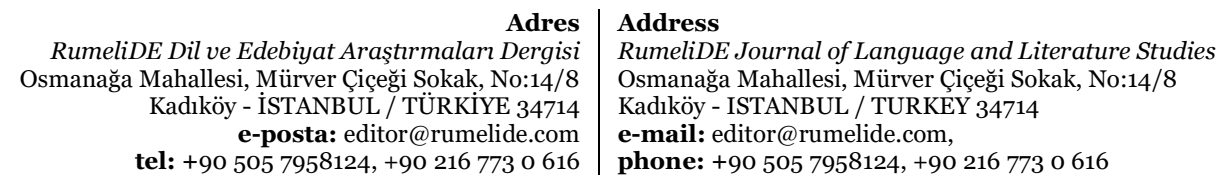


Ağladur 'uşşakın ol meh-pâre zülfin gizleyüp

Gökde bulut yog iken sihr ile bârân yağdurur

(Mu'idî, G. 85/4)

[O ay parçası (gibi güzel sevgili), zülfünü gizleyerek âşıklarını ağlatır. (Bu şekilde) gökte bulut olmadan sihirle yağmur yağdırır.]

Gözlerüñ çekdükce gamzeñ hançerin kanlar döker

Her kaçan isterse bârân yağdurur câdû gibi

(Mu'idî, G. 449/4)

[Gözlerin istediği vakitte yağmur yağdıran büyücü gibi, yan bakışının hançerini her çektiğinde kanlar döker.]

Bir ebrdür ki sihr ile bir demde yağdurup

Mülk-i 'adûyı cümle kılur lâlezâr tîg

\section{(Üsküplü İshâk Çelebi, K. 5/19)}

[Kılıç, sihirle bir anda yağıp düşman ülkesinin tamamını lâle bahçesine çeviren bir buluttur.]

\section{Yağmuru melekler yağdırır}

Meleklere iman, İslam esaslarından biridir. Meleklerin çeşitli görevleri olduğuna; bu bağlamda Mikâil'in insan da dâhil olmak üzere canlıların rızık temininde önemli bir işleve sahip olan yağmurların yağması ve bitkilerin gelişmesi gibi vazifelerle görevli olduğuna inanılmaktadır. (Cebeci, 2005: 46) Melekler, Cenab-ı Hak tarafından bazı görevleri yapmakla görevlendirilmişlerdir; ancak ismi zikredilerek Mikâîl'in tabiat kuvvetlerini idareye memur olduğu, rahmet indirdiği, yağmur yağdırıp her türlü bitkilerin, meyvelerin büyüyüp gelişmesiyle görevli olduğuna dair Kur'an ve güvenilir hadislerde bir bilgi mevcut değildir. (Çolak, 2012: 85-86)

Aşağıdaki beyitlerde âşığın aşk derdi sebebiyle ettiği âhlarının gök gürlemeleri ile, döktüğü gözyaşlarının ise yağmurla irtibatlandırıldığı görülmektedir. Gök gürlemesini, meleklerin bağırması; yıldırımı, kalplerinin kükremesi; yağmuru, ağlamaları biçiminde tasuvvur eden bilgiler de Kur'ân ve hadis kaynaklarında yer almayan bilgiler olarak durmaktadır. (Aydemir, 2000: 133; Arpaguş, 2015: 375)

Yağmurların âşığın dertli hâline üzülmeleri sebebiyle meleklerin döktüğü gözyaşları olduğu inanışı, halk kültüründe mevcuttur ve aşağıdaki beyitlerde de görüleceği üzere bu inanışa klasik şiirde sıklıkla yer verilir.

Eger kim sırrını teftîş iderseñ ra'd u bârânuñ

Melekler berk-ı âhumdan döküp yaşı ider efgân

(Zâtî, G. 1182/4)

[Gök gürültüsü ve yağmurun (oluşum) sırrını araştırırsan bu, aslında meleklerin âhımın şimşeğiyle gözyaşı döküp feryat etmelerindendir.]

Oldılar cümle feleklerde melekler eşkbâr

Göklere girdi benümçün ebr-i bârân ağladı

(Hayretî, G. 487/5)

[Feleğin her katındaki melekler, yağmur gibi gözyaşı döktüler. Yağmur bulutu benim için göklere yükselip ağladı.]

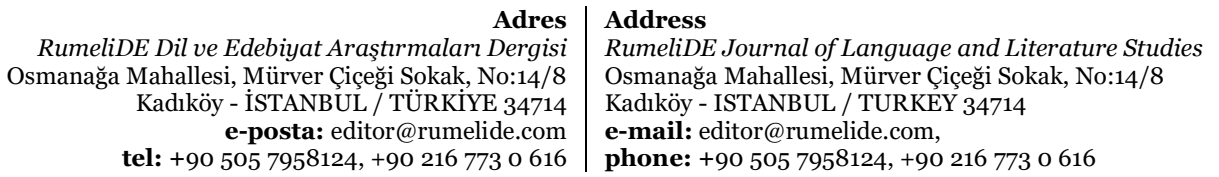

tel: $+905057958124,+902167730616$

e-mail: editor@rumelide.com

phone: +90 5057958124, +90 2167730616 
Degül ra'd u bârân görüp hâl-i zârum

Felekler melekler baña ağlar acır

(Mânî, K. 1/14)

[Gök gürültüsü ve yağmur değildir; içler acısı hâlimi gören feleklerin, meleklerin bana acıyıp ağlamalarıdır.]

Yaşum bârân olup çü ra'd-ı âhumdan firâkuñda

Felekler gümleyüp güm güm bu kevn ile mekân ditrer

(Zaî̂fî, G. 109/2)

[Ayrılığının hasretinde gözyaşım yağmur olup âhımın gök gürültüsünden felekler, güm güm gümleyip kâinat titrer.]

\section{Yağmurda mum perde ardına konur}

Tañ degül giryem görüp çekseñ nikâbuñ yüzüñe

Perde içre saklanur iy mâh bârân olsa şem

(Mưî̀î, G. 203/2)

Şairin "Ey sevgili, gözyaşlarımı görünce yüzüne peçeni örtsen bunda şaşılacak bir şey yoktur. Zira yağmur yağarken mum, perde içine saklanır." dediği yukarıdaki beyitte yer alan "şem‘in perde içre saklanması", yağmur damlalarının mumun alevini söndürmemesi için mumun çevresine gerilen bir perde ile korunması demek olup eski dönemlerde yapılan bir uygulama olmalıdır.

\section{Yağmurla ilgili ayet, hadis ve deyimler}

\section{D.1 Ayet}

\section{Yă̆mur-Ankebut}

Añlamaz hâlüm meger hem-hânem olan 'ankebûd

Ol benümle yelde yağmurda çeker mihnetleri

(Mostarlı Ziyâî, K. 11/7)

Şairin yaşadı̆̆ı evin eski, derme çatma ve çok kötü bir durumda olduğunu dile getirdiği kasidesinden alınan yukarıdaki beyitte şair, ne kadar kötü şartlarda olan bir evde yaşadığını ifade ederken "Aynı evi paylaştığımız için rüzgârlı ve yağmurlu havalarda ortak sıkıntıları yaşadığım örümcek bile benim ne zor durumda olduğumu anlayamaz." demektedir. Beyitte evin perişan hâli dile getirilirken örümcekten bahsedilmesi manidardır. Zira "Allah'tan başkasını dost edinenlerin durumu, kendilerine bir ev edinen örümceğin durumu gibidir. Evlerin en dayanıksızı ise şüphesiz örümcek evidir. Keşke bilselerdi!” (Ankebût, 29/41) ayetine telmih yapılarak örümceğin ağlarıyla kurduğu yuvasının en dayanıksız ev olarak tescil edildiği görülmektedir. Şair, beyitte olumsuz hava şartlarının özellikle rüzgâr ve yağmurun derme çatma evlerde yaşayan insanlar için hayatı ne kadar zorlaştırdığından bahsetmekte bu arada kendi durumundan da yakınmaktadır.

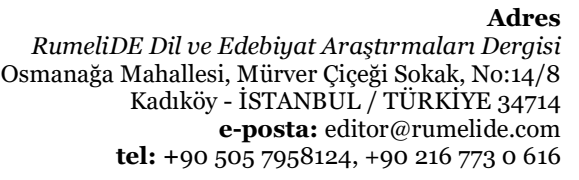

tel: +90 $5057958124,+902167730616$
Address

RumeliDE Journal of Language and Literature Studies

Osmanağa Mahallesi, Mürver Çiçeği Sokak, No:14/8

Kadıköy - ISTANBUL / TURKEY 34714

e-mail: editor@rumelide.com,

phone: +90 5057958124, +90 2167730616 


\section{D.2. Hadis}

\section{Yağmur-Gök kapısının açılması/Duaların müstecap olması}

Duanın makbul olduğu mekânlar gibi zaman dilimleri de vardır. Yağmur yağarken edilen duaların da makbul olduğu inancı bundandır. Yağmur yağdı ̆̆ında gök kapılarının açıldığı ve edilen duaların makbul olduğu inancı, "Dört yerde sema kapıları açılır ve dualar kabul edilir: Allah yolunda savaşmak üzere saf tutulduğunda, yağmur yağarken, namaz kılarken ve Kâbe’yi görünce.” (Karagöz vd., 2019: 124) hadisine dayanmaktadır. Aşağıdaki beyitte de, "Yağmur yağdığı zaman şüphesiz gök kapıları açılır." denerek bu hadise telmih yapılmaktadır.

Açllur gök kapusı yağmurda dirler lâ-cerem

Tîr-i bârân-ı gamuñdandur bu câna feth-i bâb

(Usûlî, G. 7/3)

[Yağmur yağdığı zaman şüphesiz gök kapıları açılır, derler. (Ey sevgili) Bu can için kapıların açılması ise gamının ok yağmurlarıyladır.]

\section{Yağmurun bașlangıcı mı sonu mu daha hayırlıdır bilinmez}

Hz. Enes'ten hasen hadisi olarak rivayet edilen hadiste Resulullah (s.a.v.): "Ümmetimin örneği yağmur gibidir; öncesi mi yoksa sonrası mı hayırlı bilinmez.” buyurmuştur. (Sünen-i Tirmizî Tercemesi, 2007: III/85-86) Ümmet-i Muhammed'in ilk halkası olan sahabe efendilerimiz, son halkası olarak nitelenen ahir zaman zevât-ı kiramı da büyük bir rahmet ve berekete, muazzam bir hayra mazhar olacaklardır ki değişik hadis-i şeriflerde, "Ümmetimin misali yağmur misalidir; başı mı (asr-ı saadet müslümanları), sonu mu (ahir zaman müslümanları) daha hayırlıdır bilinmez.", "Ümmetim mübarek bir ümmettir; evveli mi daha hayırlıdır, yoksa âhiri mi daha hayırlıdır bilinmez.", "Benim ümmetimin misali, Allah’ın gökten indirdiği yağmura benzer; bereketin onun başında mı sonunda mı olduğu bilinmez” (Hub, 2018: 222) gibi bazı küçük farklılıklar barındıran cümlelerle Hz. Peygamber'e ait bu hadise gönderme yapılmaktadır.

Bilinmez evveli mi âhiri mi hayrdur

Buyurdı ümmeti hakkında çünki misl-i matar

(Âşsı Çelebi, K. 14/75)

[Resulullah, yağmurun yağı̧̧ında da olduğu gibi, ümmeti hakkında öncesinin mi sonrasının mı hayırlı olduğunun bilinmediğini söyledi.]

\section{3. Deyim}

\section{Ayağına su koymak/dökmek}

Bugün yolculuğa çıkan bir kimsenin dönüşü çabuk olsun diye arkasından su dökme âdetinin eski devirlerde dışarıdan gelen bir kişiye karşı daha sık gelmesi için yapıldığı beyitlerden hareketle anlaşılmaktadır. (Şentürk, 2016: I/440) Deyim, diğer bir açıklamaya göre de ender gelen birine yarı sitem, yarı sevinçle söylenen söz (Tanyeri, 1999: 34) anlamındadır. Misafirlerin ayağına su dökmek, ona değer verildiğini gösteren bir ağırlama biçimidir. Âdetin hamama mahsus bir yönü olduğu da söylenebilir. (Zülfe, 2011: 25) Bu âdete deyimler içerisinde ayağına su dökmek ya da ayağına su koymak şekilleriyle rastlanmaktadır.

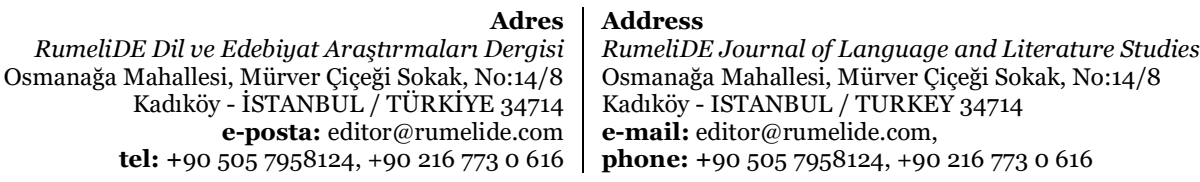

RumeliDE Journal of Language and Literature Studies 
Nâz ile salını salını gelmedi revân

Su koymalu olubdur o servüñ ayağına

(Zâtî, G. 1275/5)

[Naz ile salına salına yürüyerek gelmediği için o servinin ayağına su koymalıdır.]

Baharın müjdecisi olan güllerin ilkbahar yağmurlarıyla ıslanması, şair muhayyilesinde gülün ayağına dökülen su şeklinde değerlendirilmiştir.

Verd-i nesrîn gülsitân bezmine gec geldügiçün

Su koyar ayağına bârân ile bâd-ı sabâ

(Meâlî, G. 43/5)

[Yaban gülü; gül bahçesindeki meclise geç geldiği için sabah rüzgârı, yağmur ile ayağına su koyar.]

Yılda bir geldügiçün gül bu cihân bâgına

Geç gelürsin diyü bârân ayağına su döker

(Meâlî, G. 239/7)

[Gül, bu cihan bahçesine yılda bir kez geldiği için yağmur; (güle) geç geliyorsun, diyerek ayağına su döker.]

\section{Buluttan nem kapmak}

En küçük bir şeyden bile alınmak, çok alıngan olmak (Tanyeri, 1999: 65) anlamına gelen buluttan nem kapmak deyimi, âşığın sevgilisini hatırlatan her şey ile hüzünlenip ağlayacak duygusal bir yoğunluk yaşadığını belirtmek amacıyla kullanılmıştır. Aşağıdaki beyitlerde sevgilinin eteğini gören âşık, gözyaşlarına hâkim olamamaktadır. Muhtemelen siyah renkli olan sevgilinin eteği ile bulut arasında renge dayalı bir ilgi kurulduğu anlaşılmaktadır.

Sen içerüde dâmenüñ taşra kapudan göricek

Ağlar çü bârân gözlerüm gökde bulutdan nem kapar

(Zaî̂fî, G. 93/4)

[Kapı önünde, seni içerde eteğini dışarıda görünce gözlerim âdeta gökteki buluttan nem kapıp yağmur gibi yaş döker.]

Kapuñda görmese etegüñ yaş döker gözüm

Budur 'aceb bulut yogiken gökde nem kapar

(Za'îfî, G. 97/6)

[Gözüm, kapında eteğini görmese yaş döker. (Gözün) gökte bulut yok iken nem kapması ne gariptir.]

\section{Ocağına su koymak}

Ocağına su koymak deyimi; ocağını söndürmek, büyük zarar vermek, evini barkını yıkmak, çoluk çocuğunu yok etmek gibi anlamlara gelir. (Tanyeri, 1999: 2000; Kaya, 2011: 113) Aşağıdaki beyitte "Yağmurun, din düşmanının ocağına su koyup düşman memleketlerini suya gark edecek kadar çoğalmasını umarım.” denerek yağmurun selleri meydana getiren tahrip edici gücünün düşmanlar üzerine olması temennisinde bulunulduğu görülmektedir.

Su koyup ocağına düşmen-i dînüñ bârân

Umarın memleketin gark ide ekser deryâ

(Mostarlı Ziyâî, K. 1/6)

\begin{tabular}{|c|c|}
\hline & \\
\hline tormalar $D$ & S \\
\hline No: & Ĭ̆a Mahallesi, Mürver Çiçeği Sokak, No:14/8 \\
\hline $\begin{array}{r}\text { Kadıköy - İSTANBUL / TÜRKIYY } 34714 \\
\text { e-posta: editor@rumelide.com } \\
\text { tel: +90 505 7958124, +90 } 2167730616\end{array}$ & $\begin{array}{l}\text { Kadıköy - ISTANBUL / TURKEY } 34714 \\
\text { e-mail: editor@ rumelide.com, } \\
\text { phone: +90 505 7958124, +90 } 216773 \text { o } 616\end{array}$ \\
\hline
\end{tabular}




\section{Yağmurdan kaçıp doluya tutulmak}

Bir tehlikeden sakınmaya çahşırken daha büyük bir tehlike ile karşlaşmak (Aksoy, 1988: II/1101) anlamındaki deyimin Mesîhînnin "Gönül, gözden kaçıp meclisine vardı. (Böylece) yağmurdan kaçarken doluya tutulmuş oldu.” dediği aşağıdaki beytinde sevgiliyle ilişkilendirilerek kullanıldığı görülmektedir.

Gönül gözden kaçup bezmüñe vardı

Kaçup yağmurdan uğradı toluya

(Mesîhî, G. 242/3)

\section{Yüzüne su se(r)pmek}

Acısı, sıkıntısı azalmak, sakinleşmek, sakinleştirmek (Sefercioğlu, 2010: 200) anlamlarına gelen yüzüne su se(r)pmek deyimi, hüsn-i talilin dikkat çektiği aşağıdaki beyitte şebnemle, bulutla dolayısıyla da yağmurla ilişkilendirilmiştir. "İnciler saçan bulut, yüzüne çiy taneleri ile su serpmektedir." denen aşağıdaki beytin ikinci mısraında deyimin örneklendiği görülmektedir.

Pâyına yâ zahm urupdur hâr olupdur bî-mecâl

Şebnem ile su seper yüzine ebr-i dür-feşân

(Hayretî, K. 15/9)

\section{E. Yağmurla ilgili diğer unsurlar}

\section{Bereket}

Kültürümüzde yağmur kelimesi ile ilişkili olarak en çok anılan kavramlardan birisinin bereket olduğu söylenebilir. Yağmur, tüm canlıların su ihtiyacının karşılanmasında en önemli kaynaktır. Tarladan elde edilen mahsulün yetişmesi; çiçeğiyle, ağacıyla, çeşit çeşit bitkisiyle tabiatın canlı kalması, büyüyüp gelişmesi için suya, su için de bilhassa yağmura ihtiyaç duyulur.

Çok zamândur bitmedi kaldı ümîdüm sebzesi

Ağla İshâk ağla kim bârân ile artar çemen

(Üsküplü İshâk Çelebi, K. 13/33)

[Çoktan beri ümidimin çayırı yeşermedi gitti. Yağmur ile yeşillik büyüyüp yetiştiği için ağla, İshâk ağla.]

Kerîm bitürür hattuñı ağlatma beni gel

İy gonca dehen tîz bitürür sebzeyi bârân

(Muhibbî, G. 4034/2

[Ey gonca ağızlı sevgili, yeşillik yağmurda çabuk büyüyüp yetişir; (ama) Kerem sahibi (Allah, zaten) ayva tüylerini çıkarır; (bunun için) gel ne olur beni ağlatma.]

Mostarlı Ziyâînin "Senin ayağın uğurlu geldi. Uğradığın memleketlere yağmur yağarak toprak bereket buldu.” dediği aşağıdaki beytinde yağmurun bereketle olan ilgisine temas edilmektedir.

Bereket buldı zemîn oldı mübârek kademüñ

Geldügüñ mülkete yağdı zararsız bârân

(Mostarlı Ziyâî, K. 7/28)

\begin{tabular}{|c|c|}
\hline & \\
\hline nalar $D$ & E Journal of Language \\
\hline kak, No:1 & Osmanağa Mahallesi, Mürver Çiçeği Sokka, No:14/8 \\
\hline $\begin{array}{l}\text { Kadıköy - İSTANBUL / TÜRKIYE } 34714 \\
\text { e-posta: editor@rumelide.com }\end{array}$ & $\begin{array}{l}\text { Kadlköy - ISTANBUL / TURKEY } 34714 \\
\text { e-mail: editor@rumelide.com, }\end{array}$ \\
\hline tel: +90 $5057958124,+90216773$ o & phone: +90 $5057958124,+902167730616$ \\
\hline
\end{tabular}


Muhibbî̀ye göre yağmurla birlikte tabiatın canlanması ve renk renk çiçeklerin açılması, ibret nazarıyla bakabilenler için Allah'ın eşsiz güzellikteki sanatını müşahede etme fırsatı sunar.

Yağup bârân-ı rahmet yir yirin baş kaldurup ezhâr

Zebân-ı hâl ile eydür bu demler özge demlerdür

(Muhibbî, G. 495/2)

[Rahmet yağmuru yağıp her taraftan başkaldıran çiçekler, hâl diliyle bu anlar farklı anlardır, der.]

Dürlü çiçekler bitürdi yine bârân-ı bahâr

Kim görürse iy Muhibbî sun'-1 Yezdân'[1] okur

(Muhibbî, G. 917/5)

[Bahar yağmurları, yine çeşit çeşit çiçekler bitirdi. Ey Muhibbî, (bu çiçekleri) kim görürse Allah'ın sanatını görür.]

Meyvelerin de olgunlaşabilmesi için suya ihtiyacı vardır; ancak yağmurun çok yağması, tatlı olması beklenen bazı meyvelerdeki tatlılığı azaltır. Söz gelimi üzüm, karpuz, kavun, kiraz gibi bazı meyveler için olgunlaşma döneminde yağmurun çok yağması, istenmeyen bir durumdur. Bu dönemdeki güneşli hava ise şeker oranını artırdığı için meyvelerin tatlı olmasını sağlar. Nev'înnin aşağıdaki beyitlerinde bu hususların dile getirildiği görülmektedir.

Muttasıl çeşmüm gam-ı la'lüñle giryân eyleme

Mîvede kalmaz halâvet kesret-i bârân ile

(Nevî̀, G. 456/2)

[(Ey sevgili,) dudağının hasretiyle gözyaşlarımı sürekli akıtma. Zira yağmur çok yağarsa meyvede tatlllık kalmaz.]

Güneş kim terbiyet kılmasa kılmaz mîveler lezzet

Ne deñlü yağsa bâg-ı ‘âleme bârân-ı nîsânî

$$
\text { Nevî̀, G. 550/3) }
$$

[Nisan yağmuru, dünya bahçesine ne kadar yağarsa yağsın güneş olgunlaştırmazsa meyveler lezzetli olmaz.]

Suya ihtiyaç duyan her canlı gibi bitkiler de su ile hayatta kalır; değişik renk, koku ve şekillerdeki özelliklerini bağlık bahçelik yerlerde su vesilesiyle büyüyüp gelişmeleri sonucunda sergiler. Bu anlamda yağmur; aşağıdaki beyitte kitapları, sayfaları, binaları, çinileri renk renk boya ve çeşit çeşit desenlerdeki çizimlerle süsleyen nakkaş olarak değerlendirilmiştir.

Gözi nergis gûşı güldür berg-i sûsen kaşıdur

Bâg bir tasvîrdür bârân anuñ nakkâşıdur

(Meâlî, G. 247/1)

[(Sevgilinin) gözü nergis, kulağı gül, kaşı sûsen yaprağıdır. Bahçe, bir figürdür; yağmur, bu figürü yapan ustadır.]

Sevgilinin bindiği geminin rüzgâr gibi hızlı koşan bir ata benzetildiği, bu atın suyunun yağmur, yeminin de deniz olduğu dile getirilen aşağıdaki beyitte yağmur, içme suyu ihtiyacının karşılandığı unsur olarak görülmektedir.

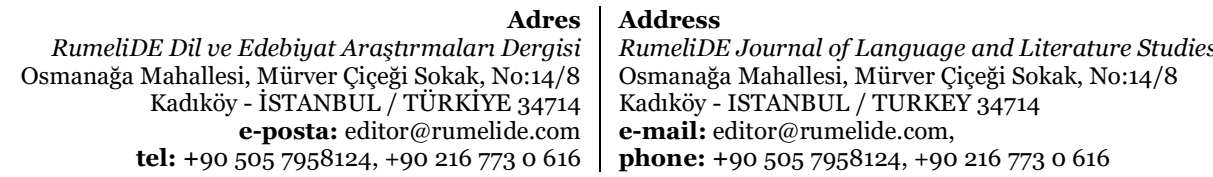

tel: $+905057958124,+902167730616$

e-mail: editor@rumelide.com 
Bâd-pâ bir rahşdur bindügi keştî dil-berüñ

İçmeğe su aña bârân yimek içün bahr yem

(Meâlî, G. 150/6)

[Sevgilinin bindiği gemi, süratli bir attır; bu atın suyu yağmur, yemi denizdir.]

Beyitlerde vurgulanan hususlardan biri de goncanın açlıp gül olmasına yağmurun tesir ettiğidir. Yağmur, bitkilerin büyüyüp gelişmesini sağlar. Goncanın da gelişmesi, gül olup açılmasında yağmurun etkisi olduğu söylenebilir. Şairlere göre, nasıl goncayı gül eden yağmur ise gonca ağızlı suskun sevgilinin açılıp aşığına iltifat etmesini sağlayan da âşıkların yağmur gibi akıttıkları gözyaşlarıdır.

Her kaçan ben ağlasam gül gibi cânânum güler

Güller açılmağa dirler ki sebeb bârân aña

(Muhibbî, G. 121/3)

[Ben ne zaman ağlarsam sevgilim, gül gibi güler (açılır). Zira güllerin açılmasının sebebinin yağmur olduğunu söylerler.]

Ağlasam ol gonca-leb handân olursa tañ mıdur

Her kaçan bârân ola gül açılur handân olur

(Muhibbî, G. 1195/6)

[Her ne zaman yağmur yağsa güller, açılıp güldü̆̆ü için ben ağlarken o gonca dudaklı sevgili, açılsa buna şaşılır mı?]

Ağlasam derd ile ol gül açılup handân olur

Gonca-veş neşv [ü] nemâ bulur kaçan bârân olur

(Helâkî, G. 38/1)

[Dert ile ağlasam o gül (gibi sevgili) açılıp neşelenir. Âdeta her yağmur yağdığında gonca gibi büyüyüp gelişir.]

\section{Cömertlik}

Gelibolulu Mustafa Âlî’nin aşağıdaki beytinde cömertlik açısından övgüsü yapılan memduhun cömertlik bulutunun yanında birbiri ardına dizilmiş at ve katır sürülerinin ancak damla mesabesinde kalacağı dile getirilmektedir. Beyitte damla-yağmur sözcükleri arasında tezada dayalı bir ilişki kurulduğu da görülmektedir.

Sehâb-ı mekrümetüñ yağmurına sultânum

Katar katırla olur at tavîlesi katarât

(Gelibolulu Mustafa Âlî, K. 52/4)

[Sultanım, senin cömertlik yağmuruna (kıyasla) art arda dizili at ve katır sürüleri damlalar (mesabesinde) olur.]

Aşağıdaki beyitlerde de yine övülen kişilerin cömertliklerinin yağmur veya bulut ile ilişkilendirildiği görülmektedir. Klasik şiirde, cömertlik ifade edilirken genellikle bârân, bârân-ı kerem, bârân-ı ihsân, $e b r-i$ cûd gibi ifadelerin kullanıldı̆̆ı görülmektedir. 
Zülâl-i lütfuñı ben hâke bârân itseñ olmaz mı

Murâdum gülșenin ser-sebz ü reyyân itseñ olmaz mı

(Gelibolulu Mustafa Âlî, K. 1486/1)

[Lütfunun hoş suyunu (ayağının altında) toprak olan bana yağmur gibi yağdırsan olmaz mı? Muradımın gül bahçesini yeşillendirip suya doyursan olmaz mı?]

İy vezâret gülşeninde serv-tek sâbit-kadem

Ebr-i kefüñden olur efşân bârân-ı kerem

(Za‘̂ifî, Muk. 1/1)

[Ey vezaret gülșeninde servi gibi sabit-kadem olan! Senin elinin bulutundan her yana cömertlik yağmuru yağar.]

Ş’ol kadar bârân-ı ihsân saçdı lutfuñ ebri kim

Oldı her arz-ı siyeh bir sebze-zâr ü kişt-zâr

(Zaî̂fî, K. 6/ 32)

[(Senin) lütfunun bulutu o kadar çok ihsan yağmurları yağdırdı ki çorak her toprak çimenlik ve ekin tarlası oldu.]

Ebr-i cûduñ yağalı ‘âleme bârân-şekil

Oldı her katresi yaşum gibi 'ummân-şekil

(Üsküdarlı 'Aşkî, K. 38/11)

[Cömertlik bulutun dünyaya yağmur gibi yağalı o yağmurun her damlası, gözyaşım gibi okyanus şeklinde oldu.]

\section{3. Çokluk}

Bir durumun çok olduğunu anlatmak için de yağmur kelimesinden yararlanılmaktadır. Beyitlerde gam, keder, ta'na taşı, tolu, mihnet, aşk gibi mefhumların çokluğunu anlatmak için yağmur kelimesinin kullanıldı̆̆ görülmektedir.

Bugün bezm içre ey sâkî tolu bârân gibi yağdı

İrişdi göklere beñzer ki ebr-i âhı mestânun

(Taşlıcalı Yahyâ Bey, G. 217/4)

[Ey sâkî, sarhoşların âh bulutu göklere ulaştı̆̆ı için, bugün mecliste şarap, yağmur gibi yağdı. ]

Gam sehâbından yağar çün başa mihnet yağmurı

Yaraşur saña Muhibbî âh u efgân eylemek

(Muhibbî, G. 1884/7)

[Muhibbî, gam bulutundan başına dertler yağmur gibi yağdığı için sana inleyip feryâd etmek yakışır.]

Hırmen-i ‘ömrüm baña virmezdi cevce hâsılı

Gözlerümden her seher yağmasa ger bârân-ı 'ışk

(Muhibbî, G. 1571/4)

[Ĕ̆er gözlerimden her seher aşk yağmuru yağmasaydı ömür harmanım, bana arpa kadar bir mahsul vermezdi.]

Muhibbî’nin yukarıdaki beytinde hırmen-i ömr terkibi dünya hayatı, cev (arpa) kelimesi nimet, mükâfât; bârân-ı ışk terkibi yoğun mücâdele, gayret, gönülden arzulamak, aşk ile gözyaşı dökmek anlamlarıyla değerlendirilebilecek şekilde kullanılmıştır. Şair, nail olduğu her nimetin ve mükâfâtın seherlerde aşk ile gayret etmesi ve gözü yaşlı bir şekilde gönülden dua etmesi sayesinde nasip olduğunu dile

Adres
RumeliDE Dil ve Edebiyat Araştırmaları Dergisi Osmanağa Mahallesi, Mürver Çiçeği Sokak, No:14/8

Kadıköy - İSTANBUL / TÜRKIYE 34714 e-posta: editor@rumelide.com

tel: +90 $5057958124,+902167730616$
Address

RumeliDE Journal of Language and Literature Studies

Osmanağa Mahallesi, Mürver Çiçeği Sokak, No:14/8

Kadıköy - ISTANBUL / TURKEY 34714

e-mail: editor@rumelide.com,

phone: +90 5057958124 , +90 2167730616 
getirmektedir. Bu bağlamda beyitte seherde gözü yaşlı bir şekilde edilen duaların makbul olduğu düşüncesinin de dolaylı olarak dile getirildiği söylenebilir. Şu hâlde aşk kavramı ile bârân-ı 'ışs şeklinde bir tamlamada kullanılmış olan yağmur kelimesi, beyitte bir yandan hem gönülden, samimiyetle, ihlâs ile hem de çok anlamlarını karşılayacak biçimde kullanılmıştır.

\section{Keçe}

Okuñ peykânı yağmur gibi yağsa hazz ider 'uşşâk

Nemed-pûşân-ı râh-ı 'ışk olan bârâna incinmez

(Gelibolulu Mustafa Âlî, G. 555/4)

Gelibolulu Mustafa Âlî’nin: “Tutulduğu aşk ile elemlere düşen kimse; eğer samimi, sadakatli bir âşık ise yaşadığı sıkıntılar ona tesir etmez, yük olarak görünmez.” dediği aşağıdaki beyitte keçeden yapılan kıyafetlerin yağmuru geçirmediğine de temas edildiği görülmektedir. Keçe, yünden dövme suretiyle yapılan bir kumaştır. Klasik Türk edebiyatında daha ziyade sözcüğün Farsçası olan nemed kullanılır. Daha çok hırka, aba, palto ve kebe denen çobanların kıyafetlerinde; evlerin döşemelerinde; çadır yapımında kullanılır. (Öztoprak, 2010: 112)

Üsküdarlı 'Aşkînnin aşağıdaki beytinde de yağmurlu havalarda keçeden yapılmış kıyafetlerin en uygun giyecek olduğu dile getirilmektedir. Bu durumda da yağmur ile keçe arasında dolaylı bir ilgi kurulmuş olmaktadır.

Hil'at-i zer-beft ile sanmañ ber-â-berdür nemed

Halka bârân-ı havâdis yağsa bihterdür nemed

(Ǘsküdarlı 'Aşkî, G. 39/1)

[Keçe, altın işlemeli kaftanla aynı değerdedir sanmayın. Halkın üstüne hadiseler, yağmur gibi yağsa keçe daha iyidir.]

\section{Mevsimler}

Yağmurların çok yağması sebebiyle yağmurla en çok irtibatlandırılan mevsim ilkbahardır. İlkbahar kadar olmasa da bu bağlamda sonbahardan ya da diğer mevsimlerdeki yağmurlardan bahsedildiği de olur. Beyitlerde doğrudan ya da dolaylı olarak yağmurlardan bahsedilen bu mevsimlerde söz; âşı̆̆a, âşı̆̆ın sevgili uğruna döktüğü gözyaşlarına getirilir ve genellikle bu yağmurlar ile âşığın gözyaşları, çokluk bakımından benzerlik ilişkisi içerisinde kullanılır.

Her kaçan görsem bahâr-ı hüsnüñi iy serv-kad

Olamaz bir lahza çeşmümden benüm bârân cüdâ

(Muhibbî, G. 85/4)

[Ey servi (boylu sevgili), her ne zaman senin güzellik baharını görsem gözyaşı yağmurum bir an bile durmaz.]

Sanki ebr-i nev-bahârîdür saña karşu gözüm

Yağdurur her dem sirişki dime bârân anda yok

(Muhibbî, G. 1586/2)

[Sana karşı gözüm, sanki ilkbahar bulutudur. Her zaman yağmur yağdırır; sakın onda yağmur yok deme.]

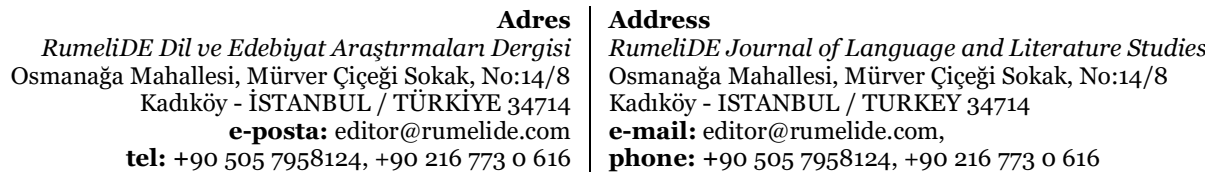

tel: $+905057958124,+902167730616$ 
Ağlamakla geçmesüñ ‘ömrüñ bahârı mevsimi

Ebr gibi olma giryân gül şen ol gülşen gibi

(Üssüplü İshâk Çelebi, G. 333/8)

[Ömrünün bahar mevsimi ağlamakla geçmesin. Bulut gibi ağlayan olma; gül bahçesi gibi gül, sevinçli ol.]

Gözümden şevk-ı dîdâruñla kuyuñda akan yaşum

Bahâr irdükde gülzâra yağan bârândan artukdur

(Üsküdarlı 'Aşkî, G. 128/2)

[(Ey sevgili,) mahallende senin yüzünün parlaklığıyla gözümden akan yaşım, bahar gelince gül bahçesine yağan yağmurdan daha fazladır.]

Ağlarsa tañ mı çeşmüm ol gül-'izâre karşu

Bârân olur bilürsiz evvel bahâre karşu

(Mu'îdî, G. 381/1)

[O gül yüzlünün karşısında gözlerimden yaş dökülürse şaşılır mı? Zira bilirsiniz ki ilkbahara doğru yağmur olur.]

Bahar mevsiminde yağmur yağdığında hava sıcaklığının düşüp havanın serinlemesi de beyitlerde değinilen hususlardandır. Bahar yağmurlarından bahsedilen çoğu yerde gülden de bahsedilmesi, havaların ısınmasıyla birlikte ilk ve en çok açılan çiçeklerden olan gülün baharın müjdecisi olarak düşünülmesinden kaynaklanıyor olmalıdır. Gelibolulu Mustafa Âlî̀nin sevgilinin yanağını güle benzettiği aşağıdaki beytinde âşığın sevgilinin karşısında ağlaması, bahar günleri yağan yağmurların oluşturduğu soğuk havalarla ilişkilendirilmiştir.

İncin baña ruhuñ güline karşu ağlasam

Hoşdur bahâr günleri bârân sovuklıgı

(Gelibolulu Mustafa Âlî, G. 146o/4)

[Yanağının gülüne karşı ağlasam bana incin. Bahar günlerinde yağmurun havayı serinletmesi güzeldir.]

Aynı şairin havalar, yaz sıcaklarına döndüğünde kış soğuklarının biteceği, yaz yağmurlarının karları eritip her yeri güzelce yıkayacağını belirttiği aşağıdaki beyitte eski edebiyatta sıklıkla karşılaşılan kış-yaz münazarasına da yer verildiği görülmektedir. Beyitte ayrıca "akın salar" ifadesiyle yaz yağmurlarının bir anda bastırıp sellere sebep olmasının ima edildiği düşünülebilir.

Nedür bu yaykara ey berf gel bürûdeti ko

Akın salar seni bârân-ı sayf oñat yaykar

(Gelibolulu Mustafa Âlî, G. 209/4)

[Ey kar, bu yaygara nedir! Gel soğukluğu bırak. Yaz yağmuru bir anda hücum ederek seni bir güzel ylkar.]

\section{Olumsuz hava}

Yağmurun çok yağması insanların önceden planladıkları işlere mâni olan olumsuz bir durum da oluşturur. Söz gelimi göç etmek ya da yolculuğa çıkmak için yağmurlu hava iyi bir vakit değildir. Zira yağmur; göç etmeyi, göç eşyasının salimen taşınmasını zorlaştıracaktır. Özellikle dağ yolları yağmurla birlikte zarar görecek, insanlar yollarını kaybedecek, yolculuk zorlaşacak ve belki de tehlikeli olacaktır. Üsküdarlı ‘Aşkî ve Gelibolulu Âlî’nin aşağıdaki beyitlerinin bu bağlamda değerlendirilmesi mümkündür.

\footnotetext{
\begin{tabular}{r|l} 
Adres & Address \\
RumeliDE Dil ve Edebiyat Araştırmaları Dergisi & RumeliDE Journal of Language and Literature Studies
\end{tabular} Osmanağa Mahallesi, Mürver Çiçeği Sokak, No:14/8 Osmanağa Mahallesi, Mürver Çiçeği Sokak, No:14/8 Kadıköy - İSTANBUL / TÜRKIYE 34714 Kadıköy - ISTANBUL / TURKEY 34714 e-posta: editor@rumelide.com e-mail: editor@rumelide.com, tel: +90 505 7958124, +90 2167730616 phone: +90 505 7958124, +90 2167730616
} 
Seyle virdi gözlerüm yaşı ser-â-ser yolları

Göçmesün ol yâre diñ billâhi bârândur bugün

$$
\text { (Üsküdarlı 'Aşkî, G. 324/2) }
$$

[Gözyaşlarım bütün yolları sele verdi. Allah aşkına, o sevgiliye söyleyin de hava yağmurlu olduğu için bugün göçmesin!]

Eşk ile gam tagınuñ güm-râhı olmışdur gözüm

Yitirür bârân ile merdüm kuhistân yolların

(Üsküdarlı 'Aşkî, G. 342/5)

[İnsan, yağmur sebebiyle dağda yolunu kaybeder ya, gözüm de gözyaşı sebebiyle gam dağında yolunu (öyle) kaybetmiştir.]

Kuhl-i hâk-i pâyı bârân itse yaşum ‘Âlîyâ

Kârvân olmaz revân râh-1 Sifâhân bağlanur

(Gelibolulu Mustafa Âlî, G. 471/5)

[Ey Âlî, sevgilinin ayağının sürme (gibi olan) toprağına gözyaşlarım yağmur gibi yağsa Isfahan yolları kapandığı için kervanlar yola çıkamaz.]

Bazen insanlar yapmak istemedikleri işler için havanın yağmurlu olmasını bir bahane olarak da kullanırlar. Aşağıdaki beyitte âşığın kendi gözyaşlarının sel oluşturacak kadar çok olmasına rağmen sevdiğine verdiği söze sadakatli iken sevgilinin yağmurlu havayı sözleşilen buluşmaya mâni bir durum olarak ileri sürmesinden şikâyeti dile getirilmektedir.

Gelmeğe mâni‘ tutup ey dôst bârân oldugin

Yaşumuñ añmaz mısın seyl-i firâvân oldugın

(Nevîi, G. 363/1)

[Ey sevgili, havanın yağmurlu olduğunu buluşma için bir engel olarak ileri sürüyorsun da benim gözyaşlarımın şiddetli sel olduğu hiç aklına gelmiyor mu?]

\section{Temizlik}

Yağmur; ağaçlarda, bitkilerde biriken tozları, sokaklardaki çeri çöpü, savaş meydanlarında dökülen kanları; hatta beden kirlerini temizler. Aşağıdaki beyitlerde özü itibariyle su olan yağmurun temizleyici özelliği üzerinde durulduğu görülmektedir.

Toz kondurmamak ister gibi sahn-ı çemene

Yüzi suyıyla gelüp hıdmet eder ebr-i bahâr

$$
\text { (Üsküplü İshâk Çelebi, G. 83/3) }
$$

[Bahar bulutu, çimenliğe toz kondurmamak istemesi sebebiyle olsa gerek yüzü suyuyla gelip hizmet eder.]

Şu deñlü bî-kes olmışdur ki Zâtî ölicek anı

Bulutlar su koyup bârân yuyup yiller götürmişdür

$$
\text { (Zâtî, G. 147/5) }
$$

[Zâtî, ölünce o kadar kimsesiz kalmıştır ki onu bulut su koyup yağmur yıkayıp rüzgâr taşımıştır.]

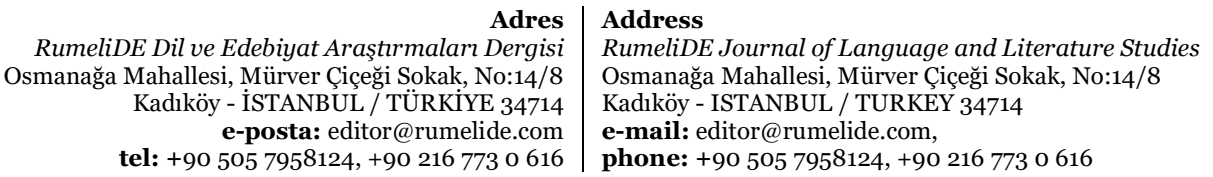

tel: $+905057958124,+902167730616$

e-mail: editor@rumelide.com,
phone: +90 $5057958124,+902167730616$ 
Şu resme lâle-veş tîgüñ yire dökdi ‘adû kanın

Anı pâk itmeye olsa hezârân Nûh Tûfânı

(Bursalı Rahmî, K. 1/17)

[Kılıcın düşman kanını lâle gibi öyle bir yere döktü ki binlerce Nuh Tufanı olsa o kanları temizleyemez.]

Yitişdi mülke halel ecnebî cünüblerden

O hâr u hasları sür dehri yayka bârân ol

(Gelibolulu Mustafa Âlî, K. 42/45)

[Devlete kirli yabancılardan fesat dokundu. (Sultanım, sen) o çer çöpleri kov. Yağmur ol, dünyayı ylka.]

\section{Ticaret}

Eski dönemlerde baharat, Hindistan'dan Avrupa'ya kadar uzanan uzun bir yolculuktan sonra müşterisiyle buluşurdu. Baharat Yolları denen bu yolun uzun, yorucu ve tehlikelerle dolu olmasının dışında, taşınan baharatın hava şartlarının olumsuz tesirlerinden korunması da büyük çaba gerektirmekteydi. Deniz yolu yanında kara yolunun da kullanılıp kervanlarla taşınan bu ticari ürünlere zarar veren olumsuz durumlardan birisi de aşağıdaki beyitten anlaşıldığına göre yağmurlu havaydı ve baharatın üstüne yağan yağmur, baharatın heba olmasına neden olmaktaydı.

Tâcir gibi bahâr yükin bağlamak diler

Bârân ki nakd-i mâ-melekin hâke itdi sarf

(Gelibolulu Mustafa Âlî, G. 637/3)

[Yağmur, tâcir gibi bahâr yükünü bağlamak istediği için, nakde değer neyi varsa toprağa harcadı.]

\section{Uyku}

Sıcak hava rehaveti artırır, nem ise uyku getirir. Yağmurlu havaların uyku getirdiği tecrübelerle sabittir. (Onay, 2009: 483) İlkbahar, yağmurların bol olduğu bir mevsimdir. Usul usul yağan yağmurun düştüğü yerde çıkardığı damla sesleri, insana tatlı bir uyku getirir. Yağmur; sesiyle, havadaki tatlı esintisiyle birlikte düşünüldüğünde yağmurlu havalarda uyumak güzeldir. Nesîmî ile Helâkî’nin aşağıdaki beyitlerinde yağmur ile uyku arasındaki bu yakın ilişkiye değinilmiştir.

Eşk-i çeşmüm gördügince hâb-1 nâz eyler gözüñ

Merdüme tatlu gelür vâkı'a bârân uyhusı

(Mesîhî, G. 265/5)

[Gözyaşlarımı her gördüğünde gözün naz uykusuna yatar. Zira insana yağmurda uyumanın tatlı geldiği hakikattir.]

Umaram kim tîr-i bârân-ı gamuñla cân virem

Hâb nûşîn olur ol sâ‘atde kim bârân olur

(Helâkî, G. 38/3)

[Yağmur yağdığında uyku tatlı olduğu için senin gam yağmurunun okuyla can vermeyi isterim.]

Âşığın çektiği aşk derdi sebebiyle döktüğü gözyaşları, bahar yağmurlarına benzetilmiştir. Özellikle çocuklarda görüldüğü üzere bir süre ağlayan insana yorgunluk hâliyle birlikte rahatlık veren tatlı bir uyku hâli de gelir. Âşık, uyku süresince olsun dertlerini unutur. Uyumak, onun zihni ve bedeni için bir

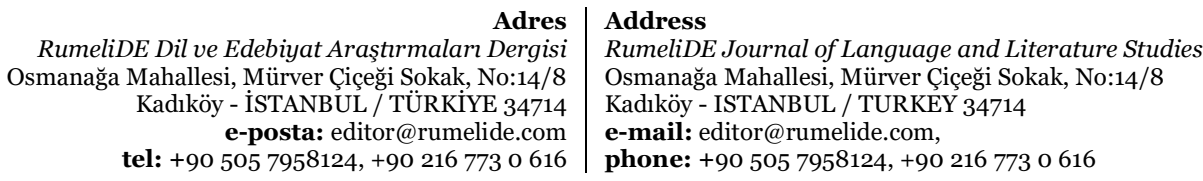


dinlenme firsatı olur. Mostarlı Ziyâînnin "Senin derdinden gözyaşlarım yağmurlar gibi akar. Bu vakitteki küçük ölüm uykusu, benim için şimdi lezzetli bir uyku olur.” dediği aşağıdaki beyitte uykunun bu rahatlatıcı etkisi dile getirilir. Beyitte geçen hâb-ı mevt ifadesinde ölüm ile uyku arasında da ilgi kurulduğu görülmektedir. İnsan uyuyunca duyu organları ya tamamen ya da kısmen faaliyetine ara vermektedir. Söz gelimi görme, koklama, tatma, duyma fonksiyonları ya da hareketler insanın uyanık olduğu hâl gibi güçlü değildir. Bu hâliyle insan, ölü bir kişiyi andırır. Kur'ân-ı Kerîm’de de, “O, geceleyin sizi ölü gibi kendinizden geçirip [uyutan] ve gündüzün kazandıklarınızı bilen, sonra da belirlenmiş eceliniz tamamlanıncaya kadar gündüzleri sizi tekrar diriltendir [canlandırandır]...” (En‘âm, 6/60) buyrulmaktadır. Ayetin ifadesinden uykunun âdeta küçük ölüm, uyanmanın ise ölümden sonraki dirilişin bir örneği olarak değerlendirildiği görülmektedir. (Soysaldı, 2018: 86)

Gamuñdan eşküm akar gör zamân-ı bârândur

Bu hâb-ı mevtüm olur şimdi baña hâb-1 lezîz

(Mostarlı Ziyâî, G. 6o/4)

Yine Mostarlı Ziyâ’i’nin "Yağmur yağdığı vakitlerde uyumak; ağlayan insanın içinin açılması, ferahlaması gibi insana güzel gelir.” dediği aşağıdaki beyitte de yağmur yağarken uyumanın güzelliği dile getirilirken ağlamanın insanı rahatlatmasına da değinilmiştir.

Hoşdur dem-i bârânda biraz uykuya varmak

Beñzer ki Ziyâ’î virür ağlamağıla cân

(Mostarlı Ziyâî, G. 356/5)

Aşağıdaki beyitlerde kendisi de dert sahibi olduğundan, başkasının hâlinden anlayan, insanlara ağlayarak içini döken âşığın şiddetli ağlamalarıyla etrafındakilere rahatsızlık ve bıkkınlık veriyor olmasından duyduğu endişe dile getirilmektedir. Sürekli ağlayan bir insan, çevresindekiler tarafından genellikle ayıplanır, sevilmez ya da bu insanın uzun uzun konuşmaları, ağlayışları bir süre sonra karşısındakinin uykusunu getirmeye başlar. Burada konuşmaların, ağlamaların âşığın derdini anlattı̆̆ı muhatabına sıkıcı gelip uykusunu getirdiği üzerinde durulmaktadır. Beyitlerde bir yandan da yağmurlu havalarda uyumanın insanlara güzel geldiği veya yağmurun insanların uykusunu getirdiğinin de ifade edildiği görülmektedir.

Ehl-i derde hâlüm ağlardum dökerdüm derdümi

Korkarın hazz itmeye yârân iñen bârândan

(Mostarlı Ziyâî, G. 323/4)

[Dert sahibi kişilere dertlerimden bahseder, hâlimi ağlayarak anlatırdım; bu dostlar, yağmurun çok yağmasından rahatsız olacaklar diye korkarım.]

Ben ağladukca ol igmâz-ı 'aynı itdi ziyâd

İşidirüz ki virür izdiyâd-ı hâb matar

\section{(Âşık Çelebi, K. 14/92)}

[Ben ağladıkça o sevgili (gözlerini kapayıp) beni görmezlikten gelmeyi daha da artırdı; (meğer) yağmur, uyku artırırmış, (bunu) yeni duyduk.]

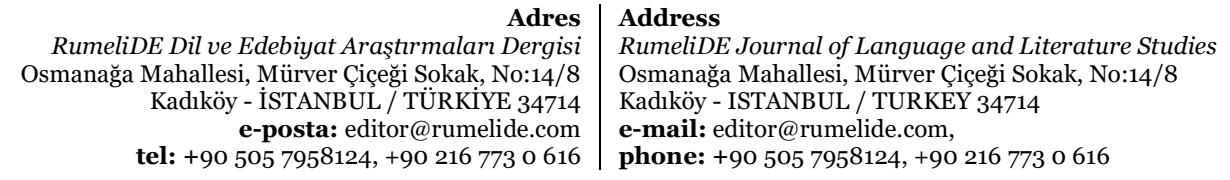

tel: $+905057958124,+902167730616$ 
Halk râhatda sehâb-ı keremüñ feyzinden

Belî uyhu getürür tab‘a hevâ-yı bârân

(Bâkî, K. 2/32)

[Senin cömertlik bulutunun yağdırdı $\breve{g}$ ihsanlar ile halk rahatlık içindedir. Evet, yağmurlu havalar, insan tabiatine uyku getirir.]

Râhat olurdum Muhibbî cevr okın yağdursa yâr

Niçe râhat olmayam ol hâb-ı bârândur baña

(Muhibbî, G. 39/5)

[Ey, Muhibbî! Sevgili, eziyet oklarını üzerime yağmur gibi yağdırsa çok rahatlardım; o oklar, benim için uyku getiren yağmurdur, nasıl rahat olmayayım ki!]

\section{Yağmurluk ve Külâh-ı bârânî (Yağmur külâhı)}

Osmanlı döneminde özellikle soğuk ve yağışlı kış günlerinde giyilen kıyafetler, hırka veya kürk üstüne keçeden yekpare Manisa yağmurluğu, çoban kepeneği, İslimye abası, Filibe abası, Yanbolu abası, deve yününden yapılmış Bağdat maşlahı, keçi yününden yapılmış siyah Van maşlahı, Bursa malı tiftikten dövme olarak yapılan Bursa arakiyye hırkası idi. Bârânî adındaki kıyafet de yeniçeri ve acemi oğlanların yağmurluğuna verilen isimdir. (Abdülaziz Bey, 1995: 226; Tietze, 2002: 279) Zâtî’nin aşağıdaki beytinde yağmurlu havalarda kullanılan yağmurluk ve külâh-ı bârânî (yağmur külâhı) yağmurla ilgili olarak değinilen eşyalardandır.

Görüp hattuñ didi çeşmüm yaşum bârânı havfinden

Siyeh yağmurlugın egnine almışdur Cemâlü'd-dîn

(Zâtî, G. 1173/2)

[Gözüm; sevgilinin ayva tüylerini görünce, gözyaşı yağmurumun korkusundan Cemalü'd-dîn sırtına siyah yağmurluğunu giymiştir, dedi.]

Aşağıdaki beyitlerden anlaşıldığına göre eski dönemlerde yağmur için külâh-ı bârânı̂ adında tepesi sivri, keçeden veya başka basit bir şeyden yapılan bir giyecek de kullanılmaktaydı. Külâh-ı bârânî’nin zıtlık ilgisiyle tac ile kullanımına dikkat edilecek olursa ve beyitte yer alan "kem-bahâ" ifadesinden hareketle bu külahın pahalı bir giyecek olmadığı anlaşılmaktadır.

Hiç tâc-ı Kubâda beñzeye mi

Kem-bahâ bir külâh-ı bârânî

(Hayâlî Bey, K. 16/31)

[Değersiz bir yağmur külâhı hiç Kubad’ın tacına benzer mi? ]

Çarh geh tâc-ı Keykubâd urınur

Geh geyer bir külâh-ı bârânî

(Üsküdarlı 'Aşkî, K. 42/6)

[Felek, bazen Keykubad tacı takınır; bazen de yağmur külâhı takar.]

\section{Sonuç}

Genel olarak yağmur üzerinde en çok durulan yön, canlılar için yaşam kaynağı olduğu, tabiata canlllık verdiği, tabiattaki varlıkların özellikle çiçeklerin büyüyüp gelişebilmesinin yağmura bağlı olduğu hususudur. İlkbahar yağmurlarının çok olduğu, sevgilinin gamze oklarının yağmur gibi âşığın sinesine

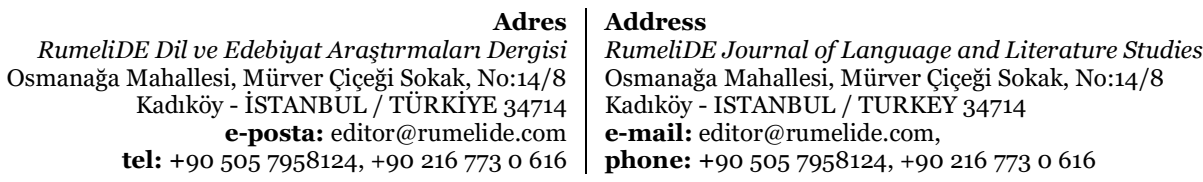


yağdı̆̆ı, yağmurun insana tatlı bir uyku verdiği ve yağmurlu havalarda uyumanın güzel olduğu yine ön plana çıkan hususlardır.

Sevgili söz konusu olduğunda bulutlar sevgilinin bazen saçları bazen kaşları olur. Âşık söz konusu olduğunda ise yağmurla en çok ilişkilendirilen unsur, gözyaşlarıdır. Bu anlamda yağmurun gözyaşı sembolü olduğu söylenebilir. Âşığın gözyaşlarıyla kendi sinesindeki yangını söndürmek istediği ve döktüğü gözyaşlarıyla sevgilisinde merhamet hissi oluşturmayı amaçladığı beyitlerde vurgulanır.

Kasideler söz konusu olduğunda yağmur, özellikle memduhun cömertliğiyle, ihsanlarıyla ilişkilendirilir ve memduhun yardım ve iyiliklerinin yağmur gibi hatta yağmurdan bile çok olduğu özellikle vurgulanan husustur.

Klasik Türk edebiyatı şairlerinin doğrudan doğruya tabiatı anlatmak yerine tabiatı ve bu bağlamda yağmuru ve yağmurla irtibatlı unsurları duygu, düşünce ve hayallerini somutlaştırarak anlatmak amacıyla bir benzetme unsuru olarak kullandıkları görülmektedir. Mesela yıldırımlar, âşığın âhları ve gökkuşağı; sevgilinin kaşı olarak tasavvur edilir. Bazen de şairler, yağmur ve unsurlarını kişileştirerek âşıkla irtibatlandırırlar. Söz gelimi bulut âşığın dertli hâline üzüldüğü için ağlar. Yağmurların bu şekilde oluştuğu dile getirilir.

Şairler, sembolleştirerek anlattıkları yağmurdan ve bulut, rüzgâr, yıldırım gibi yağmurla ilişkili diğer unsurlardan bahsederken kültürel hayata ait bilgi, âdet, deyim ve halk inanışlarına da yer verirler. Şiirlere bu gözle bakıldığında yağmur teması üzerinden şiirlerin yazıldığı dönemin duygu, düşünce hatta inanç dünyasına kapı aralamanın mümkün olduğu görülmüştür.

Şairlerin yağmurun da içinde yer aldığı tabiat unsurlarını duygularını anlatmakta bir araç olarak kullandıkları; bu sebeple de tabiatın şiirlere genellikle objektif hâliyle değil, şairlerin duygularını ifade etmekte bir araç olarak dâhil edildiği, bu anlamda şiirlerde teşbih, teşhis ve özellikle hüsn-i talillerin sıklıkla kullanıldığı görülmektedir.

Yağmur ve unsurları şairler tarafından olumlu ve olumsuz yönleri ile ele alınmış olsa da şiirlerde yağmur ve unsurları ile ilgili değerlendirmelerin daha çok olumlu olduğu görülmüştür.

Yağmurun ve yağmurla irtibatlandırılan diğer unsurların bir bütünlük içerisinde metinlerde bir arada yer almaktan ziyade şairin beyitte vurgulamak istediği anlama göre tek tek ve kısmen yer aldığı tespit edilmiştir. Yağmurla ilgili tasavvurların topluca tespiti için şiirlerin münferit olarak incelenmesinin yeterli olmayacağı açıktır. Bunun için şairlerin divanlarındaki şiirlerin tamamı incelenmeli ya da bizim de yapmaya çalıştığımız gibi belirli bir dönem içerisinde yaşamış şairlerin divanlarına topluca bakılmalı; buradan hareketle bir sonuca varılmalıdır. Böyle bir yol, kanaatimizce daha sağlıklı sonuçlara ulaşılmasını sağlayacaktır.

Klasik Türk edebiyatı kapsamındaki şiirlerde sadece soyut konulardan bahsedilmediği, şairlerinin sosyal hayattan, tabiattan kopuk olmadıkları görülmüş ayrıca şairlerin tabiattan mülhem hayaller devşirecek güçlü bir müşahede kudretine sahip oldukları tespit edilmiştir. Çalışmada üzerinde durulan yağmur temasından hareketle söylenecek olursa yağmurun rengi, kokusu, sesi gibi farklı özellikleri ile beyitlere aksettiği aynı zamanda kültürel, dini ya da yerel inanış bağlamında çok farklı kaynaklardan beslenen şairlerin geniş bilgi birikimlerine kendi şahsi gözlemlerini de ekleyerek beyitlerinde kullandıkları görülmüştür.

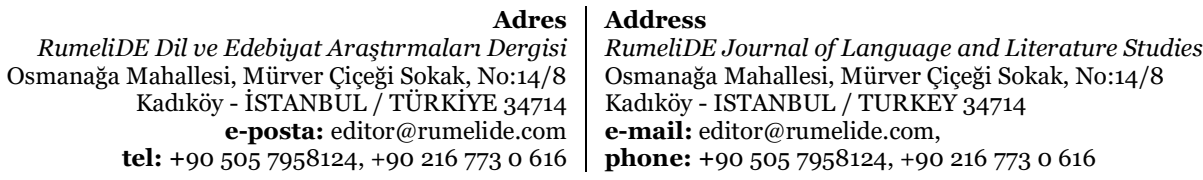




\section{Kaynakça}

\section{Yararlanılan Divanlar}

Akarsu, K. (1989). Za'ifi Divanı Metin, Tahlil ve Sistematik Endeks (Yayımlanmamış Doktora Tezi), Ankara: Gazi Üniversitesi Sosyal Bilimler Enstitüsü.

Aksoyak, İ. H. (2018). Gelibolulu Mustafâ Âlî Dîvânı, Kültür ve Turizm Bakanlı̆̆ı, e-kitap: https://ekitap.ktb.gov.tr/Eklenti/58695,gelibolulu-mustafa-alidivanipdf.pdf?o(E.T.02.03.2021)

Ambros, E. (1982). Candid Penstrokes The Lyrics of Meâlî, an Ottoman Poet of the 16th. Century, Berlin: Klaus Schwarz Verlag.

Akyüz, K. vd. (1958). Fuzûlî Türkçe Divan, Ankara: Türk Tarih Kurumu.

Aydemir, Y. (2018). Behiştî Divanı, Kültür ve Turizm Bakanlığı, e-kitap:

https://ekitap.ktb.gov.tr/Eklenti/56445,ramazan-behisti-divanipdf.pdf?o(E.T. 14.2021)

Bayak, C. (2017). Sehâbî Dîvânı, Kültür ve Turizm Bakanlığı, e-kitap: https://ekitap.ktb.gov.tr/Eklenti/55746,sehabi-divanipdf.pdf?o (E.T. o8.03.2021)

Çavuşoğlu, M. (1977). Yahyâ Bey Dîvân Tenkidli Basım, İstanbul: İstanbul Üniversitesi Edebiyat Fakültesi Yayınları.

Çavuşoğlu M. ve Tanyeri M. A. Tanyeri (1981). Hayretî Dîvan Tenkidli Basım, İstanbul: İstanbul Üniversitesi Edebiyat Fakültesi.

Çavuşoğlu, M. (1982). Helâkî Dîvan Tenkidli Basım, İstanbul: İstanbul Üniversitesi Edebiyat Fakültesi.

Çavuşoğlu M. ve Tanyeri M. A. (1987). Zâtî Divanı Gazeller Kısmı (Edisyon Kritik ve Transkripsiyon), C.3, İstanbul: İstanbul Üniversitesi Edebiyat Fakültesi.

Demirel, Ş. (2017). 16. Yüzyll Şairlerinden Mânî Dîvân ve Şehr-engîz-i Bursa, Kültür ve Turizm Bakanlı̆̆l, e-kitap: https://ekitap.ktb.gov.tr/Eklenti/55755,divan-ve-sehr-engiz-ibursapdf.pdf?o (E.T. 17.07.2021)

Erdoğan, M. (2017). Bursalı Rahmî Dîvânı, Kültür ve Turizm Bakanlığı, e-kitap: https://ekitap.ktb.gov.tr/Eklenti/55910,bursali-rahmi-divanipdf.pdf?o (E.T. 25.02.2021)

Gürgendereli, M. (2017). Mostarlı Hasan Ziyâ’î Divânı, Kültür ve Turizm Bakanlığı,ekitap:https://ekitap.ktb.gov.tr/Eklenti/56211,mostarli-hasan-ziyai-divanipdf.pdf?o (E.T. 12.02.2021)

İsen, M. (1990). Usûlî Divanı, Ankara: Akçă̆.

Keklik, M. (2014). Üsküplü İshak Çelebi Divanı (Metin-Çeviri-Açıklamalar-Dizin) (Yayımlanmamış Doktora Tezi), Bişkek: Kırgızistan-Türkiye Manas Üniversitesi Sosyal Bilimler Enstitüsü.

Kılıç, F. (2017). Âşık Çelebi Dîvânı, Kültür ve Turizm Bakanlığı e-kitap: https://ekitap.ktb.gov.tr/Eklenti/55975,asik-celebi-divanipdf.pdf?o (E.T. 13.03.2021)

Küçük, S. (2015). Bâkî Dîvânı Tenkitli Basım, Ankara: Türk Dil Kurumu Yayınları.

Mengi, M. (2020). Mesîhî Dîvânı, Kültür ve Turizm Bakanlı̆̆ı, e-kitap: https://ekitap.ktb.gov.tr/Eklenti/74203,mesihi-divanipdf.pdf?o (E.T. 02.01.2021)

Mermer, A. (2004) Kütahyalı Rahîmî ve Dîvânı, İstanbul: Sahhaflar Kitap Sarayı.

Nas, Ş. K. (2018). Celilî Dîvânı, Kültür ve Turizm Bakanlığı, e-kitap: https://ekitap.ktb.gov.tr/Eklenti/59375,celili-divanipdf.pdf?o (E.T. 01.08.2021)

Pala, İ. (1983). Aşkî, Hayâtı, Edebî Şahsiyeti ve Dîvânı, (Yayımlanmamış Doktora Tezi), İstanbul: İstanbul Üniversitesi Edebiyat Fakültesi.

Tanrıbuyurdu, G. (2018). Kalkandelenli Mu’îdî Dîvânı, Kültür ve Turizm Bakanlığı, e-kitap: https://ekitap.ktb.gov.tr/Eklenti/59883,kalkandelenli-mu39idi-divanipdf.pdf?o

(E.T. 07.03.2021)

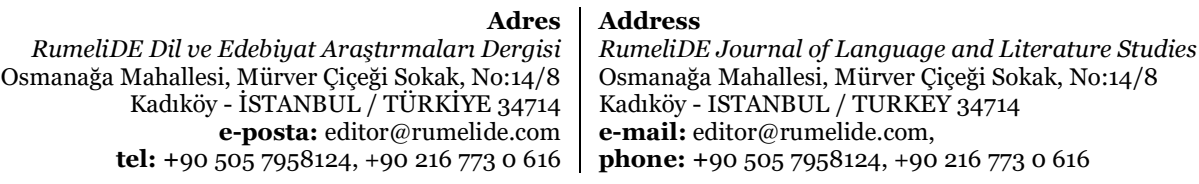

RumeliDE Journal of Language and Literature Studies 
Tarlan, A. N. (1945). Hayâlî Bey Dîvânı, İstanbul: İstanbul Üniversitesi Edebiyat Fakültesi Yayınları.

Tarlan, A. N. (1967). Zâtî Divanı Gazeller Kısmı (Edisyon Kritik ve Transkripsiyon), C.1, İstanbul: İstanbul Üniversitesi Edebiyat Fakültesi.

Tarlan, A. N. (1970). Zâtî Divanı Gazeller Kısmı (Edisyon Kritik ve Transkripsiyon), C.2, İstanbul: İstanbul Üniversitesi Edebiyat Fakültesi.

Tulum, M. ve Tanyeri M. A. (1977). Nev'î Divanı, İstanbul: İstanbul Üniversitesi Edebiyat Fakültesi.

Yavuz, K. ve Yavuz O. (2016). Muhibbî Dîvânı, C.1-2., İstanbul: Türkiye Yazma Eserler Kurumu Başkanlığı.

Uzun, S. (2011). Üsküdarlı Aşkî Divanı Tenkitli Metin, Nesre Çeviri ve 16. yy. Osmanlı Hayatının Divandaki Yansımaları, (Yayımlanmamış Yüksek Lisans Tezi), İstanbul: İstanbul Üniversitesi Sosyal Bilimler Enstitüsü.

\section{Diğer kaynaklar}

Abdülaziz Bey (1995). Osmanlı Âdet, Merasim ve Tabirleri Toplum Hayatı, İstanbul: Tarih Vakfı Yurt.

Akdağ, A. (2014). “Bir Tedavi Yöntemi Olarak ‘Kan Aldırmak’ ve Klâsik Türk Şiirindeki Kullanımı”, Gazi Türkiyat, S. 14, s. 169-187.

Aksoy, Ö. A. (1988). Atasözleri ve Deyimler Sözlüğü, C.2, Ankara: İnkılâp.

Akün, Ö. F. (2013). Divan Edebiyatı, Ankara: İsam.

Arpaguş, H. K., (2015). Osmanlı Halkının Geleneksel İslâm Anlayışı ve Kaynakları, İstanbul: Marmara Üniversitesi İlahiyat Fakültesi Vakfı.

Atalay, B. (1999). Divânü Lûgat-it-Türk Tercümesi, C.3, Ankara: Türk Dil Kurumu.

Aybet, N. (1989). Fuzûlî Dîvanı’nda Maddî Kültür, Ankara: Kültür Bakanlı̆̆ı.

Aydemir, A. (2000). Tefsirde İsrâiliyat, İstanbul: Beyan.

Batislam, H. D. (2005). "Divan Şiirinde Sabâ", Osmanh Araştırmaları, S. 26, s. 95-117.

Bayram, Y. (2007). "Klasik Türk Şiirinde Duyguların Dili: Çiçekler”, Turkish Studies, S. 2/4, s. 209-219.

Boratav, P. N. (1950). "İstiska", İslam Ansiklopedisi, C. V/II, 1221-1224., İstanbul: Milli Eğitim Bakanlığı.

Cebeci, L. (2005). "Mîkâil”, İstanbul: İslam Ansiklopedisi, TDV Yayınları, C. 30, s. 45-46.

Cunbur, M. (1985). Karacaoğlan, Ankara: Kültür ve Turizm Bakanlığı.

Çolak, A., (2012). “Kur'ân ve Hadislere Göre Melek”, Ankara: Afşar Matbaası.

Hub, M. (2018). "Rahmanî Nefhalar ve İrfânî Yorumlar: Zamanın Değer(lenmes)i ve Değerlendirilmesi Üzerine: "Nefehât Hadîsi ve Şerhi”, Toplum Bilimleri Dergisi, S.23, s.199-238.

İbrahim Cûdî Efendi (2006). Lügat-ı Cûdî (haz. İsmail Parlatır vd.), Ankara: Türk Dil Kurumu, İnan, A., (1976). Eski Türk Dini Tarihi, İstanbul: İstanbul: Kültür Bakanlı̆̆ı.

İnan, A., (1986). Tarihte ve Bugün Şamanizm Materyaller ve Araştırmalar, Ankara: Türk Tarih Kurumu. İzbirak, R. (1964). Coğrafya Terimleri Sözlüğü, Ankara: Doğuş Matbaası.

Kahraman, B. (2000). “Helâkî Dîvânı'nda Göz ve Gözyaşı”, Selçuk Üniversitesi Türkiyat Araştırmaları Dergisi, S.7, s. 233-264.

Karagöz, İ. vd., (2019). Dualar (edt. İsmail Karagöz), Ankara: Diyanet İşleri Başkanlığı Yayınları.

Kaya, H. A. (2011). “Emrî Divanı'nda Deyimler”, Divan Edebiyatı Araştırmaları Dergisi, S.6, s. 55-130.

Kemikli, B. (2007). “Divan Şiirinde Hastalık ve Tedavi”, Uludağ Üniversitesi İlâhiyat Fakültesi Dergisi, C. 16 , S. 1, s. 19-36.

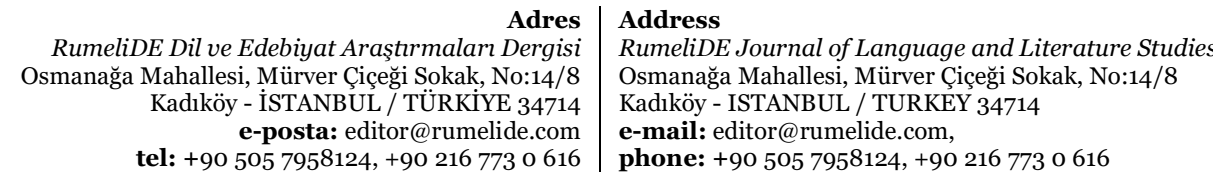

tel: +90 5057958124, +90 2167730616 
Kırbıyık, M. (2007). “Bazı XVI. Yüzyıl Divanlarında Kıymetli Taşlar”, Selçuk Üniversitesi Fen-Edebiyat Fakültesi Edebiyat Dergisi, S. 18, s. 61-75.

Kur'ân-ı Kerim Meali (2012). (haz. H. Altuntaş ve M. Şahin), Ankara: Diyanet İşleri Başkanlı̆̆ı.

Kurnaz, C. (1996). Hayâlî Bey Divânının Tahlîli, İstanbul: Millî Eğitim Bakanlığı.

Onay, A. T. (2009). Açıklamalı Divan Şiiri Sözlüğü Eski Türk Edebiyatında Mazmunlar ve İzahı (haz. Cemal Kurnaz), İstanbul: $\mathrm{H}$.

Özkan, Ö. (2007). Divan Şiirinin Penceresinden Osmanlı Toplum Hayatı, İstanbul: Kitabevi.

Öztoprak N. (2010). "Divan Şiirinde Giyim Kuşam Üzerine Bir Deneme”, Divan Edebiyatı Araşttrmaları Dergisi, S. 4, s. 103-154.

Pala, İ. (2015). Akademik Divan Şiiri Sözlüğü, İstanbul: Kapı.

Polat, B. (2007). Türk Kültüründe Yağmur Duası (Azatlı Kasabası Örneği), Dinî Araştırmalar Dergisi, S. 27., s. $275-283$.

Sefercioğlu, N. (1999). “Divan Şiirinin Çevreye Bakışı”, Türk Kültürü İncelemeleri Dergisi, S.1, s. 63-82.

Sefercioğlu, N. (2010). "Helâkî Divanı'nda Türkçe Deyimler", Divan Edebiyatı Araştırmaları Dergisi, S. 4, s. 155-202.

Selçuk, B. (2005). “Fuzûlî’de Gözyaşı”, Ekev Akademi Dergisi, S. 25, s. 233-246.

Soysaldı, H. M. (2018). "Kur'an Âyetleri ve Hadisler Perspektifinden Uyku Hakkında Bir Değerlendirme”, İnönü Üniversitesi İlahiyat Fakültesi Dergisi, S.9, s. 79-102.

Sünen-i Tirmizî Tercemesi (2007). (haz. A. Parlıyan), C. 3, Konya: Konya.

Şemseddin Sâmî (2013). Kâmûs-ı Türkî, İstanbul: Kapı.

Şentürk, A. A. (2016). Osmanlı Şiiri Kılavuzu, C.1, İstanbul: Osmanlı Edebiyatı Araştırmaları Merkezi.

Şentürk, A. A. (2017). Osmanlı Şiiri Kılavuzu, C.2, İstanbul: Osmanlı Edebiyatı Araştırmaları Merkezi.

Tanyeri, M. A. (1999). Örnekleriyle Divan Şiirinde Deyimler, Ankara: Akçağ.

TDK, (1998). Türkçe Sözlük, Ankara: Türk Dil Kurumu.

Temel Britannica Temel Eğitim ve Kültür Ansiklopedisi (1998). C. 13, İstanbul: Anan.

Tietze, A. (2002). Tarihi ve Etimolojik Türkiye Türkçesi Lügatı, C.1, İstanbul-Wien: Simurg.

Tural, S. (1993). "Edebiyat Eseri ile Çevre Arasındaki Bağlar", Türk Edebiyatında Tabiat, Ankara: Atatürk Kültür Merkezi Yayını.

Yeniterzi, E. (1999). "Divan Şiirinde Sağlık ve Hastalıklarla İlgili Bazı Hususlar”, Selçuk Üniversitesi Sosyal Bilimler Enstitüsü Dergisi, S.4, s. 87-103.

Zülfe, Ö. (2011). Şiirin İzinde Sözün Gölgesinde Osmanlı Şiirinden Kelimeler, Kavramlar, Deyimler, İstanbul: Bilge Kültür Sanat.

RumeliDE Dil ve Edebiyat Araştırmalar Dergisi Osmanağa Mahallesi, Mürver Ciçeği Sokak, No:14/8 Kadıköy - İSTANBUL / TÜRKIYE 34714 e-posta: editor@rumelide.com tel: +90 $5057958124,+902167730616$
Address

RumeliDE Journal of Language and Literature Studies

Osmanağa Mahallesi, Mürver Çiçeği Sokak, No:14/8

Kadıköy - ISTANBUL / TURKEY 34714

e-mail: editor@rumelide.com

phone: +90 505 7958124, +90 2167730616 